\title{
Geraniol, a Potential Alternative to Antibiotics for Bovine Mastitis Treatment Without Disturbing the Host Microbial Community, Does Not Lead to Drug Residues or Induce Drug Resistance
}

Guo Wei ( $\nabla$ guochina2005@126.com )

Chengdu Medical College https://orcid.org/0000-0002-1410-2361

Min Qiu

Chengdu Medical College

Zhonghui Pu

Chengdu Medical College

Nana Long

Chengdu Medical College

Min Yang

Chengdu Medical College

Ke Ren

Chengdu Medical College

Ruihong Ning

Chengdu Medical College

Siyuan Zhang

Chengdu Medical College

Lin Lin

Chengdu Medical College

Lijuan Guo

Chengdu Medical College

Yanjiao Zhang

Chengdu Medical College

Jingzhu Deng

Chengdu Medical College

Fenghui Sun

Chengdu Medical College

Min Dai

Chengdu Medical College 
Research

Keywords: mastitis, cows, geraniol, antibiotics, gut microbiome, antibacterial, anti-inflammatory, residue, drug resistance

Posted Date: September 15th, 2021

DOl: https://doi.org/10.21203/rs.3.rs-845781/v1

License: (c) (i) This work is licensed under a Creative Commons Attribution 4.0 International License.

Read Full License

Loading [MathJax]/jax/output/CommonHTML/jax.js 


\section{Abstract}

\section{Background}

Mastitis is one of the important diseases of the dairy cow. Currently, mastitis treatment in dairy cows is mainly based on antibiotics. However, the use of antibiotics causes adverse effects, including drug resistance, drug residues, host-microbiome destruction, and environmental pollution. Geraniol, extracted from Fructus Tsaoko, has demonstrated good antibacterial activity in mouse model. Geraniol and antibiotics were used to treat cows with clinical mastitis to test this possibility of geraniol as a potential alternative to antibiotics for bovine mastitis treatment. The effectiveness of treatment, improvement in inflammatory factors, the influence on microbiome, presence of drug residues, and induction of drug resistance were compared and analyzed.

\section{Results}

Geraniol demonstrated a better therapeutic rate than antibiotics on clinical mastitis of cows, with a longer course of treatment. Antibiotics and geraniol significantly reduced the abundance of pathogenic bacteria and restored the microbial community in milk. Meanwhile, geraniol increased the abundance of probiotics in milk. Interestingly, geraniol did not destroy the gut microbial community of cows, whereas antibiotics significantly reduced the diversity and destroyed the community structure of the gut microbiome in cows. Conversely, geraniol increased the diversity of the gut microbiome. Besides, no geraniol residue was detected in the milk four days after treatment discontinuation. However, antibiotic residues were detected in milk at the $7^{\text {th }}$ day after drug withdrawal. In vitro experiments revealed that geraniol did not induce drug resistance in the Escherichia coli strain ATCC25922 after 120 generations of culturing, while antibiotics induced resistance after 10 generations.

\section{Conclusions}

Our results suggest that geraniol has antibacterial and anti-inflammatory effects similar to antibiotics. Additionally, it retains the structure of the host-microbial community and does not lead to drug residues or induce drug resistance. Therefore, geraniol can be a potential substitute for antibiotics to treat mastitis and be widely used in the dairy industry.

\section{Background}

Bovine mastitis is a widespread disease causing severe risk to the global dairy industry $[1,2]$. Mastitis, an inflammation reaction of the mammary gland, is usually caused by mechanical injury, pathogen infection and decline of immunity, etc. The invasion of pathogens such as Escherichia coli [3], Staphylococcus aureus [4], Streptococcus agalactiae [5], and Mycoplasma [6] causes bacterial mastitis. The main clinical symptoms of dairy cow bacterial mastitis include a high temperature of the body, swelling of the mammary glands, abnormal production of milk, and increased somatic cells in the milk [7, 8]. Mastitis

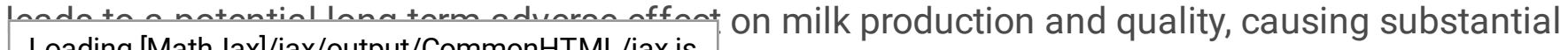
Loading [MathJax]/jax/output/CommonHTML/jax.js 
economic losses and severely restricting the sustainable development of the dairy industry $[9,10]$. Currently, antibiotics are used to treat bacterial mastitis of dairy cows [11]. However, the use and abuse of antibiotics lead to antibiotic resistance [12]. The misuse of antibiotics in animal husbandry is the main reason for increasing antibiotic resistance levels globally [13], which has become a significant threat to public health [14]. Moreover, antibiotic residues have been detected in cow's milk following antibiotic treatment [15]. The antibiotic residues are detrimental to consumer health and environmental safety [1618] and reduce milk quality [19], resulting in economic losses. Besides, the use of antibiotics disrupts the host-microbial community [20-22]. In cows, the antibiotics that kill mastitis-causing bacteria also damage the resident microbiota [23], adversely affecting host immunity, defense, and nutrient absorption $[24,25]$. Thus, antibiotics may negatively influence the health of cows. Therefore, it is urgent to explore and find a safe, green, and efficient drug to replace antibiotics to treat mastitis.

In recent years, natural medicines have become a hotspot in the field of drug research due to their advantages, such as broad-spectrum antibacterial activity, immune regulation, low drug residues, and low toxicity and resistance [26]. In the process of exploring natural medicines, several natural Chinese herbs were screened for antibacterial activity, and Fructus Tsaoko (a traditional Chinese Medicine, TCM) essential oil demonstrated obvious in vivo and in vitro antibacterial activities [27]. Besides, several studies have shown that the Fructus Tsaoko essential oil has a wide range of biological activities in animals, such as reducing plasma and liver triacylglycerol levels and antioxidant, antifungal, and hypoglycemic effects [28-31]. Geraniol and 1, 8-cineole are the main components of Fructus Tsaoko essential oil, which play a key role in defending the host from bacterial infection [27]. Geraniol is a single enolate with a molecular weight of $154.25 \mathrm{~g} / \mathrm{mol}$ [32]; it can be extracted from various aromatic plant volatile oils or obtained directly via chemical synthesis [33]. In China, geraniol has been widely used to produce pharmaceuticals, food ingredients, and spices [34,35]. Meanwhile, it is one of the most common spice ingredients in consumer products in the European market. Geraniol has good biosafety and is generally recognized as safe (GRAS) food additives by the American Spice and Extract Manufacturers Association (FEMA) and the Food and Drug Administration (FDA) [36]. It is also classified as a food flavoring compound by the Chinese national food safety standard (GB2760-2011). Geraniol has many pharmacological activities, such as analgesic, antibacterial, anti-inflammatory, antioxidant, anti-ulcer, antifungal, and insecticidal effects [37-41]. In addition, increasing attention has been paid to the antitumor activity of geraniol [41-44]. Geraniol has also demonstrated protective effects on the liver, heart, and nerves $[41,43,45]$ and regulated apoptosis $[45,46]$. Therefore, geraniol, a widely used resource for drugs and foods, can be used as an active ingredient and a chemical adjuvant for drug development.

TCM have been used to treat diseases by regulating gut microbiota structure [47-49]. The mechanism of action includes two aspects: inhibiting harmful bacteria and protecting beneficial bacteria $[49,50]$. Unlike antibiotics, TCM treat diseases without disturbing the host-microbial community; they even restore the bacterial community structure destroyed by antibiotics [51, 52]. In a previous study, geraniol demonstrated in vitro and in vivo antibacterial activities against strains isolated from clinical bovine mastitis samples [53], such as Escherichia coli, Streptococcus agalactiae, Staphylococcus aureus and Loading [MathJax]/jax/output/CommonHTML/jax.js as an alternative to antibiotics in treating clinical mastitis of 
dairy cows. Therefore, geraniol was used to treat clinical mastitis using antibiotics as the control in the present study. Several parameters, including the effectiveness of the treatment, the medicine's effect on the host microbial community, drug residues in milk, and drug resistance in bacteria, were analyzed.

\section{Materials And Methods}

\section{Strains and mice for infection model}

Before using geraniol to treat bovine mastitis, a preliminary experiment was conducted in mice to evaluate its efficacy, safety, and dosage. Geraniol was used to treat mice infected with Escherichia coli, one of the main pathogenic bacteria causing bovine mastitis. The bacterium was isolated from cow milk with clinical mastitis and stored in the Sichuan Experimental Teaching Demonstration Center for Medical Testing of Chengdu Medical College (Chengdu, China). Specific pathogen-free (SPF) Kunming (KM) mice (male; body weight, $20 \pm 2 \mathrm{~g}$ ) provided by Sichuan Chengdu Institute of Biological Products Co., Ltd. (Chengdu, China) were used in the experiment.

\section{Mouse model of $E$. coli infection}

After adaptive feeding for 2 weeks in the laboratory, $80 \mathrm{KM}$ mice were randomly divided into eight groups $(n=10)$, including seven experimental groups and one blank group. The pathogen $E$. coli was cultured at a constant temperature of $37^{\circ} \mathrm{C}$ in Luria-Bertani (LB) medium $(50 \mathrm{~mL})$ until the logarithmic phase. The bacterial culture was diluted using physiological saline to seven concentrations $\left(5.85 \times 10^{7}, 2.925 \times 10^{7}\right.$, $3.663 \times 10^{6}, 3.663 \times 10^{6}, 1.831 \times 10^{6}, 1.371 \times 10^{6}$, and $0.911 \times 10^{6}$ ) and mixed with $5 \%$ porcine stomach mucin (Sigma, St Louis, MO, USA). The E. coli solution was intramuscularly injected into seven experimental groups, and the mice in the blank group were intraperitoneally injected with the same volume of normal saline. On the premise that the blank control group mice did not die, the mortality of the mice in the experimental group was recorded within 72 hours (every 12 hours). The minimum concentration that caused the death of all mice in a group was considered as the minimum lethal dose (MLD) of E. coli. Meanwhile, the lowest bacterial load that killed half of the mice was considered the half lethal dose $\left(\mathrm{LD}_{50}\right)$ of $E$. coli.

Further, $90 \mathrm{KM}$ mice were randomly divided into eight groups $(\mathrm{n}=10)$, including blank group, E. coli infection group, solvent group, positive control group, and five treatment groups. The blank group and $E$. coli infection group were injected intramuscularly with normal saline; the solvent group was injected intramuscularly with Twain-80; the positive control group was injected intramuscularly with cefotaxime $(0.3 \mathrm{~g} / \mathrm{kg})$; and the geraniol treatment groups were injected intramuscularly with different doses of geraniol $(0.261 \mathrm{~g} / \mathrm{kg}, 0.166 \mathrm{~g} / \mathrm{kg}, 0.107 \mathrm{~g} / \mathrm{kg}, 0.07 \mathrm{~g} / \mathrm{kg}$, and $0.045 \mathrm{~g} / \mathrm{kg})$. Each mouse was injected once daily for 5 days. After the last intramuscular injection, mice in all groups, except the blank group, were intraperitoneally injected with the MLD of E. coli. The survival rate of the mice was observed within 7 days after $E$. coli challenge, and the dose of geraniol that maintained $50 \%$ survival rate of mice was 


\section{Assessment of antibacterial activity of geraniol in mouse infection model}

Mice infected with $\mathrm{LD}_{50}$ of $E$. coli were treated with the $\mathrm{ED}_{50}$ of geraniol to evaluate its efficacy. Forty KM mice were randomly divided into four groups $(\mathrm{n}=10)$, including the control group, half lethal $E$. coli infection group, the geraniol treatment group, and the antibiotic treatment group. Half lethal $E$. coli infection group, antibiotic treatment group, and geraniol treatment group were challenged with the $L_{50}$ of $E$. coli, and then intramuscularly injected with saline, cefotaxime, and geraniol $\left(E_{50}\right)$, respectively. The control group was challenged with the same dose of inactivated $E$. coli, and intramuscularly injected with saline. Saline, cefotaxime $(0.3 \mathrm{~g} / \mathrm{kg})$, and geraniol $(0.26 \mathrm{~g} / \mathrm{kg})$ were administered once a day for five consecutive days.

Further, blood was collected from the eyeball venous plexus of mice at $0.5 \mathrm{~d}, 1 \mathrm{~d}, 2 \mathrm{~d}, 3 \mathrm{~d}$, and $7 \mathrm{~d}$ after infection to determine the dynamic changes in routine blood index. TEK- $\$ MINI A3-0052 three-class blood cell counter (Tekang Technology, China) was used to determine the different blood parameters, including white blood cell (WBC) count, absolute lymphocyte (LYM) value, absolute intermediate cell (MID), absolute granulocyte (GRA) value, red blood cell (RBC) count, hemoglobin (HGB), hematocrit (HCT), mean red blood cell volume (MCV), mean hemoglobin content $(\mathrm{MCH})$, mean hemoglobin concentration $(\mathrm{MHCH})$, platelet (PLT) count, platelet packed volume (PCT), and average platelet volume (MPV). All the experiments were completed within $24 \mathrm{~h}$ after blood collection.

Fresh fecal samples of mice were collected for monitoring the dynamic changes in the gut microbiome. Fecal samples were collected before $(0 \mathrm{~h})$ and after $(12 \mathrm{~h})$ E. coli infection to evaluate the effect of infectious pathogens on the mouse gut microbiome. Samples collected before infection were used as a baseline ( 0 day) of the mouse gut microbiome. Fecal samples were also collected on $1^{\text {st }}, 7^{\text {th }}, 14^{\text {th }}$, and $28^{\text {th }}$ days after treatment. All samples were quickly frozen in liquid nitrogen and transferred to $-80{ }^{\circ} \mathrm{C}$ freezer until further analysis. The schematic diagram of the experiment is shown in Fig. S1A.

\section{Oral administration of geraniol in healthy mice}

Further, the effect of oral geraniol on the community structure of the gut microbiome in animals was analyzed. Healthy mice were fed with geraniol or antibiotics, and the dynamic changes in the gut microbiota of mice were examined. Thirty mice were divided into three groups $(n=10)$, including the control group, oral antibiotic group, and oral geraniol group. The mice of the antibiotic and geraniol groups were fed cefotaxime and geraniol, respectively, via gavage from $1^{\text {th }}$ to $3^{\text {th }}$ day, once a day. The therapeutic dose $\left(E D_{50}\right)$ was chosen as the oral feeding dose. The mice of the control group were fed normal saline by gavage. Fecal samples were collected from all mice on day 0 (prior to the experiment), 1 , $3,7,14$, and 28. The schematic diagram of the experiment is shown in Fig. S1B.

\section{Experimental set up in dairy cows}

The study was conducted on a dairy farm in Chengdu, Sichuan Province, China, from April 2020 to 
from Uruguay. This study did not involve any endangered or protected animal species and did not cause any harm to the experimental animals. Cows were provided a standard diet composed of grass-legume hay to meet the daily nutrient requirements for milk production. The cows did not receive antibiotics or other drugs during the past two months. Somatic cell count (SCC, the number of leukocytes per milliliter of fresh milk) and clinical symptoms were used to diagnose mastitis [54]. A Bentley FTS/FCM400 Combi Instrument (Chaska, USA) was used to measure SCC in the milk. Cows with SCC $<2 \times 10^{4} \mathrm{cells} / \mathrm{mL}$ and no obvious signs of clinical mastitis, such as breast redness and heat, and no damaged nipple ends were diagnosed as healthy, while those with $\mathrm{SCC}>2 \times 10^{6} \mathrm{cells} / \mathrm{mL}$ and symptoms such as breast redness, swelling, heat and pain, elevated body temperature, and abnormal milk color were considered as infected cows (mastitis). A total of 12 healthy and 25 infected (mastitis) cows were recruited for this study. The mastitis group was divided into the antibiotic treatment group $(n=13)$ and the geraniol treatment group $(n=12)$; the drug was injected into the cows' breasts. Detailed information on the individual cows and grouping is presented in Table S1.

\section{Mastitis treatment and sample collection}

In the geraniol treatment group, each cow with mastitis was injected $1.18 \mathrm{~g}$ of geraniol twice a day. In the antibiotic treatment group, each cow with mastitis was injected $10 \mathrm{~g}$ of cefalexin and kanamycin monosulfate intramammary infusion (Cephalexin: Kanamycin = 2:1; Tullyvin, Cootehill, Co. Cavan, Ireland), once a day. Treatments were carried out for 5 days. The cows with mastitis that showed no significant improvement on the 7 day after treatment were considered incurable by the drug. Fresh stool, milk, and blood samples collected at 0 days (before the experiment) were considered baseline. Materials were also sampled on $3^{\text {rd }}, 5^{\text {th }}$, and $14^{\text {th }}$ days. The middle part of the fresh stool was collected immediately after defecation using a sterile fecal collector. The nipples were wiped with iodine and $75 \%$ ethanol and cleaned using sterile distilled water to collect milk without pollution. While sampling, the first three milk strands were discarded, and then the milk $(50 \mathrm{~mL})$ was squeezed into a sterile centrifuge tube. The venous blood was obtained using a sterile syringe. Blood was centrifuged at $3000 \mathrm{rpm}$ for $5 \mathrm{~min}$ to get the serum. These serum samples were stored at $-4{ }^{\circ} \mathrm{C}$ while feces and milk samples were stored in a $-80^{\circ} \mathrm{C}$ freezer until further analysis. The schematic diagram of the experiment is shown in Fig. S1C.

\section{Detection of inflammatory cytokines in cows}

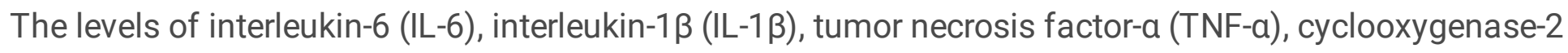
(COX-2), and inducible nitric oxide synthase (iNOS) in the serum of dairy cows with clinical mastitis were measured using enzyme-linked immunosorbent assay (ELISA) kits, according to the manufacturer's instructions. All ELISA kits were purchased from Shanghai Future Industrial Co., Ltd. (Shanghai, China).

\section{Bacterial DNA extraction, 16S rRNA sequencing, and bioinformatic analysis}

Bacterial total genomic DNA was extracted using the Mo Bio PowerFecal DNA isolation kit (Mo Bio Laboratories, Carlsbad, CA, USA), following the manufacturer's instructions. For the stool samples, a Loading [MathJax]/jax/output/CommonHTML/jax.js ; transferred directly to the PowerBead tubes for extracting 
total genomic DNA. For milk samples, $10 \mathrm{~mL}$ of each sample was centrifuged at $12,000 \mathrm{~g}$ for $5 \mathrm{~min}$ at 4 ${ }^{\circ} \mathrm{C}$ to remove the lipid layer from the milk. The supernatant was discarded, and the watercourse was collected and filtered through a filter membrane $(0.2 \mu \mathrm{m})$. The filter membrane was transferred to the PowerBead tubes to extract the bacterial total genomic DNA. NanoDrop (Thermo Fisher Scientific, Waltham, USA) was used to measure the concentration and purity of the genomic DNA. The quality of DNA was assessed by agarose gel electrophoresis. Only samples that met the following criteria were used for PCR: (1) DNA concentration > $5 \mathrm{ng} / \mathrm{uL}$; (2) total DNA > $150 \mathrm{ng}$; and (3) complete and contamination-free DNA fragment. The universal 515F/806R barcoded primer pair (515F:

GTGCCAGCMGCCGCGGTAA, 806R: GGACTACHVGGGTWTCTAAT) [55] was used to amplify the V4 region of the bacterial $16 \mathrm{~S}$ rRNA gene. The PCR reaction mixture $(50 \mu \mathrm{L})$ contained $2 \mu \mathrm{L}$ DNA $(20 \mathrm{ng}$ per sample), $25 \mu \mathrm{L} 2 \times$ NEB Phusion High-Fidelity PCR Master Mix, $2 \mu \mathrm{L}(0.4 \mu \mathrm{M})$ forward primer, $2 \mu \mathrm{L}(0.4 \mu \mathrm{M})$ reverse primer, and $19 \mu \mathrm{L}$ sterile double-distilled water. The thermocycling parameters were as follows: 95 ${ }^{\circ} \mathrm{C}$ for $3 \mathrm{~min}$, followed by 30 cycles of $95^{\circ} \mathrm{C}$ for $45 \mathrm{~s}, 56^{\circ} \mathrm{C}$ for $30 \mathrm{~s}$, and $72{ }^{\circ} \mathrm{C}$ for $90 \mathrm{~s}$, and a final extension at $72{ }^{\circ} \mathrm{C}$ for 10 min. AmpureXP beads (Agencourt Beckman Coulter, Beverly, MA, USA) were used to purify the PCR products. Sequencing libraries were constructed using the MiSeq Reagent Kit v2 (Illumina, CA, USA). PCR, sequencing library construction, and paired-end sequencing (Illumina MiSeq platform) were executed at Novogene (Beijing, China).

The 16S rRNA gene raw sequences were pre-processed and analyzed using the QIIME2 pipeline (version 2019.9) [56]. DADA2 software within QIIME2 was utilized to filter low quality (< Q20), chimeric, and erroneous reads [57]. Sequence variants were aligned based on the MAFFT program [58]. Further, a phylogenetic tree based on the clean reads was constructed using FASTTREE algorithm [59]. Meanwhile, sequences identified as chloroplast and mitochondria were filtered out. Taxonomy was assigned to operational taxonomic units (OTUs) using BLAST to align representative sequences to the SILVA database (version 132) [60], and singleton OTUs were removed from downstream analysis. The OTU tables were rarefied to the minimum number of reads per sample before alpha or beta diversity analysis to eliminate the bias caused due to variant sequencing depth. Alpha-diversity indices, including the number of observed OTUs and Shannon's diversity index, were calculated using QIIME2. PCoA (Principal Co-ordinate Analysis) was performed based on weighted UniFrac distances in QIIME2 to measure the similarity in the bacterial community between the samples [61].

\section{Determination of drug residues in milk of dairy cows after antibiotic or geraniol injection}

After injection of antibiotics and geraniol into the mammary gland, the drug residues in milk were determined every day from the $1^{\text {st }}$ to the $7^{\text {th }}$ day after stopping administration. The geraniol standard (purity $>98 \%$, No. SHBL2152), HPLC-grade acetonitrile (ACN), and methanol (MeOH) were purchased from Sigma-Aldrich (St. Louis, MO, USA). Cephalexin (purity $>98 \%$, No. 130408-201411) and kanamycin (purity $>98 \%$, No. 130556-201502) were obtained from National Institute for Food and Drug Control (Beijing, China). The residue of geraniol in milk was detected and analyzed by gas chromatography-mass spectrometer (GC-MS; Agilent 7890A/5977B gas chromatography-mass spectrometer system) (Santa

Loading [MathJax]/jax/output/CommonHTML/jax.js :xin and kanamycin residues were analyzed by high-

Page $8 / 37$ 
performance liquid chromatography (HPLC; Agilent LC-1260, Agilent Technologies, Santa Clara, CA, USA). GC-MS analysis for the residues in the milk samples was carried out according to a previously reported method [27], and the residues of cephalexin and kanamycin in milk samples was detected in accordance with the national standards GB/T 21314-2007 [62] and GB/T 22969-2008 [63], separately. Further, the specificity of the method was determined by analyzing the chromatographic peaks of the standard and the milk samples to assess the accuracy of the method.

\section{Assessment of geraniol and antibiotics induced bacterial drug resistance}

Geraniol and amoxicillin were used to induce drug resistance of bacteria in vitro to verify whether geraniol causes pathogenic bacteria to develop drug resistance. The standard strain (E. coli, ATCC25922) stored at $-80^{\circ} \mathrm{C}$ was inoculated onto an agar plate and cultured at $37^{\circ} \mathrm{C}$ for $24 \mathrm{~h}$ to obtain a single colony. Prepare E. coli into 0.5 Michaelis concentration unit $\left(1.5 \times 10^{8} \mathrm{CFU} / \mathrm{mL}\right)$ with sterile normal saline and diluted 100 times with Mueller-Hinton Broth (MHB) medium. Then, geraniol emulsion $(86 \mathrm{mg} / \mathrm{mL})$ mother liquor was prepared with Tween-80 as an emulsifier, while amoxicillin was dissolved in sterile water, and the amoxicillin mother liquor was prepared at a concentration of $4096 \mu \mathrm{g} / \mathrm{mL}$. The geraniol emulsion and amoxicillin mother liquor were diluted into 12 different concentrations by double dilution to determine their minimum inhibitory concentration (MIC). Further, $1 \mathrm{~mL}$ of MHB culture solution, $0.5 \mathrm{~mL}$ of diluted geraniol solution, and $0.5 \mathrm{~mL}$ of the standard strain $\left(1.5 \times 10^{8} \mathrm{CFU} / \mathrm{mL}\right)$ were added into the test tube one after the other. The final concentration of geraniol and amoxicillin in the test tube was maintained ranging from 0.02 to $43.00 \mathrm{mg} / \mathrm{mL}$ and 1 to $2048 \mu \mathrm{g} / \mathrm{mL}$, respectively. This mixture was incubated at $37^{\circ} \mathrm{C}$ for $24 \mathrm{~h}$ to observe the growth of the standard strain. The standard strain without drug was used as the positive control, while drug alone with no bacteria was used as the negative drug control, and tubes containing only culture medium were blank controls. The minimum drug concentration that inhibited the growth of the standard strain was taken as the MIC value of the bacteria. After the MIC value was determined, geraniol/amoxicillin solution at the sub-inhibitory concentration (1/2MIC) and the standard strain ( 0.5 Michaelis concentration) were added to the MHB medium. These strains were cultured at $37^{\circ} \mathrm{C}$ and $200 \mathrm{rpm}$ for $24 \mathrm{~h}$ as the first-generation resistant strains induced by drugs. Following the above method, the first-generation resistant strain was repeatedly cultured with geraniol/amoxicillin to obtain the second-generation strain, and the MIC values of geraniol and amoxicillin were determined every ten generations.

\section{Statistical analysis}

Significance differences between the mean values of three or more groups were analyzed using the Kruskal-Wallis test followed by the post-hoc Dunn's multiple comparison test in GraphPad Prism 7 (GraphPad Software, Inc., USA). Mann-Whitney U test was used to compare the differences in mean values between two groups. The result graphs were created using "boxplot," "barplot," "ggplot2", and "plot" functions in base R (version 3.5) [64]. 


\section{Mouse model of $E$. coli infection}

The mice's MLD and $\mathrm{LD}_{50}$ of $E$. coli were $2.925 \times 10^{7}$ and $0.911 \times 10^{6} \mathrm{CFU} / \mathrm{kg}$, respectively (Table S2). After 5 days of prophylactic administration of geraniol, significant antibacterial activity was observed in the mice challenged with MLD of E. coli. Geraniol at $0.261 \mathrm{~g} / \mathrm{kg}$ completely $(100 \%)$ prevented $E$. coli infection. With the decrease in dose, the prevention rate decreased. Kirschner's method found $0.261 \mathrm{~g} / \mathrm{kg}$ as the $\mathrm{ED}_{50}$ of geraniol against $E$. coli infection in mice (Table S3).

\section{Therapeutic effect of geraniol on mice infected with $\mathrm{LD}_{50}$ of $E$. coli}

Similar to cefotaxime, geraniol cured (100\%) infection in mice challenged with $\mathrm{LD}_{50}$ of $E$. coli (Table S4). The routine blood indices, including WBC, LYM, MID, GRA, PCT, PLT, RBC, MPV, and MCV, decreased significantly after infection ( $<<0.05$; Fig. S2). After treatment with cefotaxime and geraniol, these indices increased (Fig. 1), and finally reached a level similar to that of the control mice. Among them, LYM, MID, RBC, MPV, and MCV were restored to significantly higher levels in the geraniol treatment group than in the antibiotic treatment group. No significant difference was observed in the other index levels between the two treatment groups after being cured. Thus, the results confirm that geraniol helps in better recovery of the low blood routine indexes of mice caused due to bacterial infection than cefotaxime.

\section{Effects of antibiotics and geraniol on gut microbiota community structure of mice during infection}

A total of 96 fecal samples were obtained from 16 mice at six different time points. After filtering lowquality sequences and ambiguous bases, 8,059,359 clean reads were reserved for subsequent analysis; the number of clean reads per sample varied from 70,560 to 93,853 (Table S5). Further, the OTU table was rarified to a depth of the minimum number of sequences per sample to correct the differences caused by the sequencing depth. The rarefaction curve of each sample attained stability at the lowest sequencing depth (randomly subsampling 70,000 reads; Figs. S3A, B).

Furthermore, the alpha diversity indices (Shannon index and the number of observed OTUs; Figs. S4A, B) and PCoA (Fig. S4C) of gut microbiota in the E. coli infection mice after E. coli infection were not significantly different compared with the pre-infected mice. After treatment with cephalexin, alpha diversity indices, including Shannon index (Fig. 2A) and the number of observed OTUs (Fig. 2B), declined significantly. The diversity of gut microbiota decreased significantly on the $1^{\text {st }}, 7^{\text {th }}$, and $14^{\text {th }}$ days after intraperitoneal injection of antibiotics $(p<0.05)$, and it did not return to normal until the $28^{\text {th }}$ day. This observation suggested that the gut microbiota was destroyed after antibiotic treatment (Fig. 2E). The phylogenetic distance between the gut microbiota after $\left(1^{\text {st }} / 7^{\text {th }} / 14^{\text {th }} / 28^{\text {th }}\right.$ day $)$ and before treatment was significantly larger than that within the samples before treatment (the $0^{\text {th }}$ day) (Fig. $2 F ; p<0.05$ ), considering the gut microbiota of mice before treatment as the baseline. After geraniol treatment, the Shannon index and the number of observed OTUs of gut microbiota did not show a significant downward trend, while those on the $28^{\text {th }}$ day were significantly higher than those on the $1^{\text {st }}$ and $7^{\text {th }}$ day $(p<0.05$; 
administration (Fig. 2G). The phylogenetic distance between the gut microbiota after $\left(1^{\text {st }} / 7^{\text {th }} / 14^{\text {th }} / 28^{\text {th }}\right.$ day) and before treatment (the $0^{\text {th }}$ day) was not significantly different from the distance within the samples before treatment (the $0^{\text {th }}$ day) $(p>0.05$; Fig. $2 \mathrm{H})$.

\section{Effect of geraniol direct feeding on gut microbiome of mice}

Further, mice orally administered with geraniol and antibiotics were analyzed; after filtering the ambiguous bases and low-quality sequences, 11,812,564 clean reads were obtained from 30 mice at six different time points, with 50,645 to 75,491 reads per sample (Table S6). The lowest sequencing depth $(50,000)$ sampling analysis showed that the rarefaction curves approached saturation (Figs. S5A, B).

Alpha diversity indices, including Shannon index (Fig. 3B) and the number of observed OTUs (Fig. 3E), decreased significantly after the mice were fed cefotaxime. From the $1^{\text {st }}$ to $7^{\text {th }}$ day after providing cefotaxime by oral gavage, the diversity of mouse gut microbiota continued to decrease. The diversity began to recover on the $14^{\text {th }}$ day after the experiment (the $10^{\text {th }}$ day after stopping cefotaxime orally); however, it did not return to normal level until the $28^{\text {th }}$ day. On the contrary, the Shannon index (Fig.3C) and the number of observed OTUs (Fig. 3F) of mouse gut microbiota did not show a downward trend after feeding geraniol. The alpha diversity indices were similar to that of the control mice (Figs. 3A, D). On the $28^{\text {th }}$ day after the experiment, the number of observed OTUs in the mice fed with geraniol was significantly higher than before ( 0 days; Fig. $3 F$ ). PCoA indicated that gut microbiota composition in the

geraniol group and control group did not change significantly during the whole experiment $\left(0^{\text {th }}\right.$ to $28^{\text {th }} ; p>$ 0.05 ; Fig. $3 G$ ). However, the PCoA of gut microbiota in mice was obviously destroyed after feeding cefotaxime, and it did not return to the state before administration by the $28^{\text {th }}$ day $\left(24^{\text {th }}\right.$ day after stopping treatment; $p<0.001$; Fig. $3 G$ ).

\section{Therapeutic effect of geraniol against mastitis in dairy cows}

Dairy cows suffering from mastitis had significantly decreased somatic cells in the milk (Fig. 4A). After 5 days of treatment with geraniol and antibiotics (cefotaxime and kanamycin), the SCC in the milk of dairy cows with mastitis significantly reduced (less than $2 \times 10^{6}$ cells $/ \mathrm{mL}$ ) (Figs. 4B, C), and the clinical symptoms subsided (Table S7). In the treatment via breast infusion, the cure rate was $76.92 \%$ with geraniol, and the average cure time was 7 days, while the cure rate was $66.67 \%$ with antibiotics, and the average cure time was 6 days (Table S7). These observations suggest that the average cure rate of geraniol was higher than that of antibiotics, while the average cure time of antibiotics was shorter than that of geraniol.

\section{Geraniol treatment reduces inflammation in dairy cows}

In the process of inflammation, pro-inflammatory mediators, including IL-1 $\beta$, IL-6, TNF-a, COX-2, and iNOS, are produced at the inflammation site. The levels of IL-1 $\beta$, IL-6, TNF-a, COX-2, and iNOS in the serum of cows with clinical mastitis were significantly higher than those of healthy cows $(p<0.001$; Fig. S6). After 
injecting antibiotics and geraniol into the breast of dairy cows with clinical mastitis, the levels of these inflammatory factors ( $L-1 \beta$, IL -6, TNF- $\alpha, C O X-2$, and iNOS) in the blood decreased (Fig. 5). By the $14^{\text {th }}$ day after administration with geraniol or antibiotics, the levels of inflammatory factors returned to normal levels (Fig. 5).

\section{Mastitis altered milk composition and fecal bacteria in dairy cows}

After filtering ambiguous bases and low-quality sequences, 5,854,637 clean reads were obtained from 92 milk samples, with 41,475 to 132,153 reads per sample (Table S8). Rarefaction analysis by randomly subsampling showed that the rarefaction curve of each sample attained stability at the lowest sequencing depth (randomly subsampling 40,000 reads, Fig. S7). The alpha diversity indices (the Shannon index and the number of observed OTUs) of the bacteria in the milk (Figs. 6A, B) and gut (Figs. $7 A, B)$ of cows with mastitis were significantly lower $(p<0.05)$ than in the healthy dairy cows. PCoA indicated that the structure of milk (Fig. 6C) and gut (Fig. 7C) microbiota in the cows with mastitis was distinct from the healthy dairy cows. Mastitis resulted in a significant increase in the intraindividual variations in milk (Fig. 6D) and gut (Fig. 7D) microbiota, and the phylogenetic distance between the healthy group and mastitis group was more than that within the healthy or mastitis group. Dairy cows with mastitis showed a significant imbalance in milk microbiota. Mastitis significantly increased the relative abundances of Enterobacteriaceae (cows with mastitis, $0.546 \pm 0.075$; healthy cows, $0.027 \pm$ 0.009), Streptococcus (cows with mastitis, $0.184 \pm 0.041$; healthy cows, $0.005 \pm 0.004$ ), and Mycoplasma (cows with mastitis, $0.072 \pm 0.079$; healthy cows, $0.005 \pm 0.037$ ), but reduced that of normal bacteria in milk (Figs. 6E), such as Ruminococcaceae, Clostridiales, Bacillales and Clostridium. However, no obvious change in the relative abundance of predominant phylum (top 10) and genus (top 20) of gut microbiota was observed between cows with mastitis and healthy cows (Figs. 7E, F).

\section{Geraniol decreases the relative abundance of pathogenic bacteria and increases the relative abundance of probiotics in the milk of dairy cows with mastitis}

On the $3^{\text {rd }}, 5^{\text {th }}$, and $14^{\text {th }}$ day after antibiotic treatment, the Shannon index of milk microbiota in mastitis cows was significantly higher $(p<0.05)$ than that before treatment, but only on the $5^{\text {th }}$ day after antibiotic treatment, the number of observed OTUs was significantly higher $(p<0.05)$ than that before the treatment (Figs. 8A, B). Meanwhile, the Shannon index of milk microbiota in cows with mastitis increased significantly $(\mathrm{p}<0.05)$ on the $5^{\text {th }}$ and $14^{\text {th }}$ days after geraniol treatment $(\mathrm{Fig} .8 \mathrm{C})$. In addition, the number of observed OTUs was significantly higher $(p<0.05)$ on the $5^{\text {th }}$ and $14^{\text {th }}$ days after geraniol treatment than that before treatment (Figs. 8D). The antibiotic treatment group and geraniol treatment group showed significant recovery in the community structure, making it similar to the normal milk microbiota (Figs. 8E, F). Certainly, antibiotics resulted in a faster recovery of milk microbiota community structure of sick cows than geraniol. After three days of antibiotic treatment, the milk microbiota of dairy cows with mastitis was closer to that of healthy dairy cows, while geraniol treatment took 14 days to restore the milk microbiota of dairy cows with mastitis similar to that of healthy dairy cows (Figs. 8E, F). 
After treatment with antibiotics and geraniol, the relative abundance of pathogenic bacteria (Enterobacteriaceae, Streptococcus, and Mycoplasma) in milk decreased significantly $(p<0.05)$ (Figs. 8G, $\mathrm{H})$. In the antibiotic treatment group, the relative abundance of Enterobacteriaceae, Streptococcus, and Mycoplasma decreased to $0.026 \pm 0.006,0.003 \pm 0.001$, and $0.06 \pm 0.005$, respectively, on the $14^{\text {th }}$ day after treatment (Fig.8G), while that in the geraniol treatment group decreased to $0.04 \pm 0.01,0.004 \pm$ 0.002 , and $0.02 \pm 0.01$, respectively (Fig. $8 \mathrm{H}$ ). The relative abundance of probiotics including Lactobacillus and Bifidobacterium in the milk of cows with mastitis significantly increased $(p<0.05)$ with geraniol treatment ( $3^{\text {rd }}$ and $5^{\text {th }}$ days; Figs. $9 C, D$ ); however, the abundance of these probiotics did not increase significantly in the antibiotic treatment group (Figs. 9A, B).

\section{Gut microbiota in cows remain safe during mastitis treatment with geraniol}

After filtering the ambiguous bases and low-quality sequences, 6,640,249 clean reads were produced from 92 feces samples, with 48,879 to 90,793 reads per sample (Table S9). The lowest sequencing depth $(40,000)$ sampling analysis showed saturation of the rarefaction curves (Fig. S8).

Antibiotic treatment of mastitis significantly reduced the diversity of gut microbiota. After antibiotic injection, the Shannon index and number of observed OTUs of gut microbiota in cows declined, with no recovery by the $14^{\text {th }}$ day (10 days after discontinuing antibiotics) (Figs. 10A, B). Conversely, the Shannon index (Fig. 10C) and the number of observed OTUs (Fig. 10D) increased steadily after receiving geraniol. On the $14^{\text {th }}$ day ( $10^{\text {th }}$ day after stopping geraniol) after geraniol treatment, the Shannon index and number of observed OTUs of gut microbiota in cows with clinical mastitis was significantly higher than that before treatment.

Furthermore, PCoA based on weighted Unifrac distance showed that the structure of gut microbiota of cows with mastitis got destroyed after antibiotic treatment (Fig.10E). On the $10^{\text {th }}$ day after discontinuing antibiotic treatment $\left(14^{\text {th }}\right.$ day), the structure of gut microbiota showed the biggest variation compared with that before treatment. The phylogenetic distance between the gut microbiota after $\left(5^{\text {th }} / 14^{\text {th }}\right.$ day) and before treatment was significantly larger $(p<0.05)$ than that within the samples before treatment (Figs. 10F). However, geraniol did not destroy the community structure of gut microbiota in cows during the treatment (Fig. $10 \mathrm{G}$ ); the phylogenetic distance in the gut microbiota of cows with mastitis between the $3^{\text {th }} / 5^{\text {th }} / 14^{\text {th }}$ day after receiving geraniol treatment and before treatment did not show a significant increase $(p>0.05)$ compared with the distance within the samples before the treatment (the $0^{\text {th }}$ day) (Fig. $10 \mathrm{H})$

\section{Geraniol has a short residual time in cow's milk}

A total of 140 milk samples from 20 cured cows (each cow was sampled once a day for seven consecutive days) of the geraniol treatment group $(n=10)$ and the antibiotic treatment group $(n=10)$ were collected to detect the residues of the drug in the milk. Cephalexin and kanamycin were identified by comnarina thn rntantinn timn nf comnlnc with the standard. Cephalexin (Fig. S9) and kanamycin (Fig. 
S10) standards showed a distinct single peak, with a retention time of 2.162 min and 9.241 min, respectively; cephalexin (2.197) and kanamycin (9.282) in milk demonstrated almost similar retention times, and a better resolution was observed within 10 min and 20 min, respectively. Cephalexin and kanamycin remained in the milk of cured cows on the $7^{\text {th }}$ day after cephalexin and kanamycin injection (Table 1). Meanwhile, the quantitative analysis of the antibiotic residues indicated that the daily metabolism only reduced the residue dose of antibiotics by 0.1 to 0.4 times daily; even worse, no reduction in cephalexin and kanamycin residues were detected in the milk of five cows within two or three days. No matrix peaks were observed in the chromatograms that interfered with the geraniol residue analysis (Fig. S11); it suggested that GC-MS can accurately detect the residues of geraniol in milk. Besides, the retention time of geraniol was $35.1 \mathrm{~min}$ (Approximately) and the mass fragment selected for evaluation was m/z 154. No geraniol residue (no peak in $35.0 \mathrm{~min}$ ) was detected in the milk of cows on the $4^{\text {th }}$ day after stopping geraniol treatment. Additionally, no geraniol residue was detected in the milk of one cow (CG_5) on the first day after stopping geraniol (Table 2). Furthermore, quantitative analysis of drug residues showed that the geraniol residues decreased 6 times day by day after stopping geraniol.

\section{Geraniol retains antibacterial activity and results in less pathogen resistance}

The initial MIC values of geraniol and amoxicillin for the Escherichia coli strain ATCC25922 were $33.6 \mu \mathrm{g} / \mathrm{mL}$ and $4 \mu \mathrm{g} / \mathrm{mL}$, respectively. The MIC value of geraniol for the tested bacteria did not change after being induced by sub-inhibitory concentration for 120 generations (Fig. 11A), while the MIC value of amoxicillin increased eight times $(32 \mu \mathrm{g} / \mathrm{mL})$ by the $10^{\text {th }}$ generation, 256 times $(1024 \mu \mathrm{g} / \mathrm{mL})$ by the $20^{\text {th }}$ generation, and 512 times $(2048 \mu \mathrm{g} / \mathrm{mL})$ by the $40^{\text {th }}$ to $120^{\text {th }}$ generations (Fig. $\left.11 \mathrm{~B}\right)$. This result suggests that long-term use of geraniol will not lead to bacterial resistance.

\section{Discussion}

The present study found that geraniol has the same effect as antibiotics in restoring inflammatory factors in cows with clinical mastitis. Studies have reported an increase in the levels of TNF-a and IL-6 in the sera and milk of cows with clinical mastitis; these factors play a key role in promoting inflammation of the mammary gland [65]. COX-2, iNOS, and IL-1 $\beta$ are the inflammatory mediators in the clinical diseases of dairy cows. Studies have correlated the abnormal expression of these factors with metabolic disorders and diseases in dairy cows $[66,67]$. Therefore, the present study's results suggest that geraniol reduces the inflammation of mammary gland in cows with clinical mastitis, consistent with the earlier reports on anti-inflammatory and antioxidant effects in the rat model of Metabolic Syndrome (MetS) [68]. However, studies on geraniol anti-inflammatory properties mainly focused on model mouse [68-70]. This study provides the first direct evidence for the role of geraniol in reducing inflammatory factors in dairy cows with a naturally occurring disease. Moreover, the disease cure rate with geraniol was higher than that with antibiotics. However, geraniol took longer to cure the dairy cows with clinical mastitis, indicating the difference in the mechanism of action between traditional Chinese medicine and antibiotics.

Generally, antibiotics act against infectious diseases by directly killing the pathogenic bacteria, whereas Loading [MathJax]/jax/output/CommonHTML/jax.js ate anti-infectious properties via comprehensive action [71], 
such as inhibiting or killing the pathogenic bacteria $[72,73]$ (usually not as good as antibiotics), immune regulation [74, 75], and anti-inflammatory activity [76]. Therefore, geraniol demonstrated a better mastitis cure rate with a longer course of treatment.

Furthermore, both geraniol and antibiotics restored the milk microbiota of cows with mastitis. The diversity of milk microbiota in the cows with mastitis was significantly improved after breast perfusion treatment with antibiotics or geraniol. Meanwhile, the proportion of pathogenic bacteria (Enterobacteriaceae, Streptococcus, and Mycoplasma) in the milk of cows with mastitis was as high as $80 \%$, which led to the low diversity. Treatment with antibiotics or geraniol effectively inhibited these pathogenic bacteria, quickly restoring the diversity of milk microbiota. Studies using a third-generation antibiotic cephalosporin to treat cow mastitis have confirmed that antibiotics significantly improve diversity [23], consistent with the present study's results. Generally, Enterobacteriaceae [77], Streptococcus [78], and Mycoplasma [79] are the environmental pathogenic bacteria that cause mastitis in cows. In the present study, too, cows with mastitis were mainly infected with these three pathogens. Geraniol, like antibiotics, reduced the relative abundance of pathogenic bacteria and eventually restored the structure of the milk microbiota damaged due to mastitis. However, geraniol takes longer to restore the diversity and community structure of dairy cow milk microbiota compared with the antibiotics. This slow action is probably related to the characteristics of TCM. The compound kills the pathogenic bacteria directly and inhibits the pathogenic bacteria through immune regulation [75], anti-endotoxin [80], and antiinflammatory action [76]. Together, these observations suggest that geraniol can be used to treat cow mastitis more mildly. In addition, geraniol significantly improved the relative abundance of Lactobacillus and Bifidobacterium, the common probiotics in farm animals [81]. These probiotics enhance the immunity of dairy cows, increase the milk yield, and reduce pathogenic bacteria during livestock breeding [82]. Nagahata et al. reported that the intramammary infusion of Bifidobacterium breve eliminated pathogens and decreased SCC in dairy cows with chronic subclinical mastitis [83]; it also enhanced innate immune response in mammary glands in lactating dairy cows [84]. Meanwhile, feeding Lactobacillus casei and Lactobacillus plantarum improved the quality and quantity of cow milk production [85]. It can be concluded that geraniol inhibits pathogenic bacteria and increases the abundance of probiotics, helping the dairy cows with mastitis maintain long-term health and milk yield. Various herbs (Black Cumin, Curcuma zeodharia, Curcuma mangga, and Curcuma aeruginosa) have been confirmed to significantly increase the milk yield, milk protein content, and milk lactose content in subclinical mastitis cows and significantly decrease mastitis [86]. However, no antibiotic has demonstrated this characteristic. Further studies are required to verify if increased abundance of probiotics in milk plays a key role in anti-infection and maintains milk yield of dairy cows.

In the dairy industry, the treatment of bovine clinical mastitis is mainly based on the extensive use of antibiotics [87]. However, the microbiota in the rumen and rectum of cows get significantly changed after antibiotic exposure, and the structure of the microbial community does not been restored for a long time (>18 days) after withdrawing the antibiotics [88]. In the present study, too, the community structure of intestinal microflora in dairy cows and mice was seriously damaged after treatment with antibiotics, Loading [MathJax]/jax/output/CommonHTML/jax.js le frame analyzed. The gut microbiome is necessary and 
beneficial for the host; these microbes help in development [89], harvesting energy [90], defending pathogens [25], and regulating immunity [91]. Therefore, antibiotic treatment of dairy cows may lead to deterioration in their health status. Interestingly, though geraniol destroyed the community structure of the gut microbiome, it increased the diversity, maintaining the health of infected cows. An experimental Chinese medicinal formula alleviated ulcerative colitis (UC) symptoms in model mice via restoration of gut microbiota diversity and function of gut microbiota [49]. Similarly, geraniol mediated an increase in the gut microbiome diversity in dairy cows, which may also play a role in resisting pathogenic bacteria and anti-inflammatory response.

Furthermore, antibiotic residues were detected in the milk of dairy cows for an extended period ( $>7$ days) after withdrawing the antibiotics, with a significant impact on the health of dairy cows and environmental safety. Antibiotic residues has been reported to destroy the gut microbiome and affect the health of calves [92]. Several studies have reported antibiotic residues in milk for 18 days [93], which is a global health threat [94]. Milk with antibiotic residues will affect human health and promote the development of antibiotic resistance. However, discarding milk with antibiotic residues leads to huge economic losses for the dairy industry. It also causes antibiotic pollution to the environment [95]. Meanwhile, geraniol residues were detected in milk for a short time. Moreover, the compound does not pose a threat to the host. These advantages of geraniol are incomparable with antibiotics. Besides, the in vitro antimicrobial experiments showed that antibiotics induced bacterial resistance, while geraniol hardly caused resistance. This characteristic is common to traditional Chinese medicines, probably due to the multiple mechanisms responsible for the antibacterial property [96]. However, more studies are needed to reveal the specific mechanisms underlying the anti-infective property of geraniol. Finally, geraniol, a single enolate compound obtained from Chinese herbal medicine such as Fructus Tsaoko or easily available via chemical synthesis [33], can be used as a cost-effective treatment option for mastitis, replacing antibiotics for broad application in the dairy industry.

\section{Conclusion}

The present study demonstrated the ability of geraniol to treat cows with clinical mastitis caused by multiple pathogens, with a cure rate higher than that of antibiotics. Geraniol increased the abundance of probiotics in milk, resulted in fewer drug residues, and induced minimal pathogenic drug resistance. In conclusion, geraniol can be a potential alternative to antibiotics for treating clinical mastitis in dairy cows. However, this study did not reveal the specific mechanism via which geraniol cures clinical bovine mastitis. In the future, we need more research to reveal the mechanism of geraniol in curing dairy cow mastitis, further, the role of microbiome in resisting pathogens also needs to be investigated.

\section{Abbreviations}

FEMA: American Spice and Extract Manufacturers Association; FDA: the U.S. Food and Drug Administration; SPF: Specific pathogen-free; KM: Kunming; LB: Luria-Bertani; MLD : minimum lethal dose; $\mathrm{ED}_{50}: 50 \%$ effective dose; WBC: white blood cell count; 
LYM: absolute lymphocyte value; MID: absolute intermediate cell; GRA: absolute granulocyte value; RBC: red blood cell count, HGB: hemoglobin; HCT: hematocrit; MCV: mean red blood cell volume; $\mathrm{MCH}$ : mean hemoglobin content; $\mathrm{MHCH}$ : mean hemoglobin concentration; PLT: platelet count; PCT: platelet packed volume; MPV:average platelet volume; SCC: Somatic cell counts; IL-6: interleukin-6; IL-1 $\beta$ : interleukin-1 $\beta$; TNF-a: tumor necrosis factor- $\alpha$; COX-2: cyclooxygenase-2; iNOS: inducible nitric oxide synthase; ELISA: enzyme linked immunosorbent assay; PCR: polymerase chain reaction; GC-MS: gas chromatographymass spectrometer system; MHB: Mueller-Hinton Broth; MIC: minimum inhibitory concentration: PCoA: principal coordinate analysis; MetS: Metabolic Syndrome; UC: alleviating Ulcerative colitis

\section{Declarations}

\section{Ethics approval and consent to participate}

This study was approved by the Institute of Animal Care and the Ethics Committee of Chengdu Medical College. All animal experiments (animal production license number: SCXK2020-08) were conducted according to the approved guidelines and regulations.

\section{Consent for publication}

Not applicable

\section{Availability of data and materials}

The dataset used in this study was deposited into NCBI's Sequence Read Archive (SRA) under accession bioproject number: PRJNA747729.

\section{Competing interests}

The authors declare that they have no competing interests.

\section{Funding}

This work was supported by the National Natural Science Foundation of China (No. 31970137 and No.31900307), the Sichuan Science and Technology Program (No.2021YJ0158, No. 2020YJ0401, No.2020JDRC0071), the science and technology project of the health planning committee of Sichuan (No.19PJ032).

\section{Authors' contributions}

M.D. and W.G. designed this study. W.G., M.Q and M.D. wrote this manuscript. W.G., M.D., F.S. and M.Q. analyzed the data. Z.P., M.Q., W.G. and N.L. performed the laboratory experiments. K.R., R.N., S.Z., L.L., L.G., Y.Z. and J.Z. collected the samples. M.Y. provide suggestions for manuscript writing. All authors revised the manuscript, and approved the submission of this article. 


\section{Acknowledgements}

We thank Mr. Li Wang for carrying out the treatment experiment of mastitis and collection of feces and blood samples in cows.

\section{References}

1. Dahl M, De Vries A, Maunsell F, Galvão K, Risco C, Hernandez J. Epidemiologic and economic analyses of pregnancy loss attributable to mastitis in primiparous Holstein cows. Journal of Dairy Science. 2018; doi: 10.3168/jds.2018-14619.

2. Rollin E, Dhuyvetter K, Overton M. The Cost of Clinical Mastitis in the First 30 Days of Lactation: an Economic Assessment Tool. Preventive Veterinary Medicine. 2015;122:257; doi:

10.1016/j.prevetmed.2015.11.006.

3. Ganda E, Gaeta N, Sipka A, Pomeroy B, Oikonomou G, Schukken Y, et al. Normal milk microbiome is reestablished following experimental infection with Escherichia coli independent of intramammary antibiotic treatment with a third-generation cephalosporin in bovines. Microbiome. 2017;5; doi: 10.1186/s40168-017-0291-5.

4. Naushad S, Nobrega Diego B, Naqvi SA, Barkema Herman W, De Buck J, Kent Angela D. Genomic Analysis of Bovine Staphylococcus aureus Isolates from Milk To Elucidate Diversity and Determine the Distributions of Antimicrobial and Virulence Genes and Their Association with Mastitis. mSystems. 5(4):e00063-20; doi: 10.1128/mSystems.00063-20.

5. Keefe G. Streptococcus agalactiae mastitis: A review. The Canadian veterinary journal La revue vétérinaire canadienne. 1997;38:429-37.

6. Geary SJ, Tourtellotte ME, Cameron J. Inflammatory toxin from Mycoplasma bovis: isolation and characterization. Science. 1981;212(4498):1032-3.

7. Ruegg P. A 100-Year Review: Mastitis detection, management, and prevention. Journal of Dairy Science. 2017; 100:10381-97; doi: 10.3168/jds.2017-13023.

8. Gunasegaram Narayana S, Schenkel F, Miglior F, Chud T, Abdalla E, Naqvi SA, et al. Genetic analysis of pathogen-specific intramammary infections in dairy cows. Journal of Dairy Science. 2020;104; doi: $10.3168 /$ jds.2020-19062.

9. Dalanezi FM, Joaquim S, Guimarães FF, Guerra S, Lopes BC, Schmidt EMS, et al. Influence of pathogens causing clinical mastitis on reproductive variables of dairy cows. Journal of Dairy Science. 2020;103; doi: 10.3168/jds.2019-16841.

10. Fogsgaard K, Bennedsgaard T, Herskin M. Behavioral changes in freestall-housed dairy cows with naturally occurring clinical mastitis. Journal of dairy science. 2014;98; doi: 10.3168/jds.2014-8347.

11. Guardabassi L, Apley M, Olsen J, Toutain P-L, Weese S. Optimization of Antimicrobial Treatment to Minimize Resistance Selection. Microbiology Spectrum. 2018;6; doi: 10.1128/microbiolspec.ARBA0018-2017. 
12. Brennan E, Martins M, McCusker M, Wang J, Alves B, Hurley D, et al. Multidrug-Resistant Escherichia coli in Bovine Animals, Europe. Emerging Infectious Diseases. 2016;22; doi: 10.3201/eid2209.160140.

13. Pal C, Bengtsson-Palme J, Kristiansson E, Larsson J. The structure and diversity of human, animal and environmental resistomes. Microbiome. 2016;4:54; doi: 10.1186/s40168-016-0199-5.

14. Shankar PR. Antimicrobial Resistance: Global Report on Surveillance. Australasian Medical Journal. 2014;7:237.

15. Liljebjelke K, Warnick L, Witt M. Antibiotic residues in milk following bulbar subconjunctival injection of procaine penicillin $\mathrm{G}$ in dairy cows. Journal of the American Veterinary Medical Association. 2000;217:369-71; doi: 10.2460/javma.2000.217.369.

16. Kümmerer K. Antibiotics in the aquatic environment - A review - Part II. Chemosphere. 2009;75(4):435-41; doi: https://doi.org/10.1016/j.chemosphere.2008.12.006.

17. Marazuela-Lamata MD, Bogialli S. Review of novel strategies of sample preparation for the determination of antibacterial residues in foodstuffs using liquid chromatography-based analytical methods. Analytica chimica acta. 2009;645:5-17; doi: 10.1016/j.aca.2009.04.031.

18. Normanno G, La Salandra G, Dambrosio A, Quaglia N, Corrente M, Parisi A, et al. Occurrence, characterization and antimicrobial resistance of enterotoxigenic Staphylococcus aureus isolated from meat and dairy products. International journal of food microbiology. 2007;115:290-6; doi: 10.1016/j.jfoodmicro.2006.10.049.

19. Hospido A, Sonesson U. The environmental impact of mastitis: A case study of dairy herds. The Science of the total environment. 2005;343:71-82; doi: 10.1016/j.scitotenv.2004.10.006.

20. Kuperman A, Koren O. Antibiotic use during pregnancy: How bad is it? BMC Medicine. 2016;14; doi: 10.1186/s12916-016-0636-0.

21. Cho I, Yamanishi S, Cox L, Methé B, Zavadil J, Li K, et al. Antibiotics in early life alter the murine colonic microbiome and adiposity. Nature. 2012;488:621-6; doi: 10.1038/nature11400.

22. Cox L, Yamanishi S, Sohn J, Alekseyenko A, Leung J, Cho I, et al. Altering the Intestinal Microbiota during a Critical Developmental Window Has Lasting Metabolic Consequences. Cell. 2014;158:70521; doi: 10.1016/j.cell.2014.05.052.

23. Ganda E, Bisinotto R, Lima S, Kronauer K, Oikonomou G, Schukken Y, et al. Longitudinal metagenomic profiling of bovine milk to assess the impact of intramammary treatment using a thirdgeneration cephalosporin. Scientific Reports. 2016;6; doi: 10.1038/srep37565.

24. Porcellato D, Meisal R, Bombelli A, Narvhus JA. A core microbiota dominates a rich microbial diversity in the bovine udder and may indicate presence of dysbiosis. Scientific Reports. 2020;10(1):21608; doi: 10.1038/s41598-020-77054-6.

25. Kamada N, Chen G, Inohara N, Nunez G. Control of Pathogens and Pathobionts by the Gut Microbiota. Nature immunology. 2013;14:685-90; doi: 10.1038/ni.2608.

26. Harvey AL, Edrada-Ebel R, Quinn RJ. The re-emergence of natural products for drug discovery in the Loading [MathJax]/jax/output/CommonHTML/jax.js covery. 2015;14(2):111-29; doi: 10.1038/nrd4510. 
27. Min D, Cheng P, Fenghui S. Anti-infectious efficacy of essential oil from Caoguo (Fructus Tsaoko). Journal of Traditional Chinese Medicine. 2016;36(6):799-804; doi: https://doi.org/10.1016/S02546272(17)30018-3.

28. Yu L, Shirai N, Suzuki H, Sugane N, Hosono T, Nakajima Y, et al. The Effect of Methanol Extracts of Tsao-ko (Amomum tsao-ko Crevost et Lemaire) on Digestive Enzyme and Antioxidant Activity In Vitro, and Plasma Lipids and Glucose and Liver Lipids in Mice. Journal of nutritional science and vitaminology. 2010;56:171-6; doi: 10.3177/jnsv.56.171.

29. Moon S-S, Lee J-Y, Cho S-C. Isotsaokoin, an Antifungal Agent from Amomum t sao-ko. Journal of natural products. 2004;67:889-91; doi: 10.1021/np030464l.

30. Martin TS, Kikuzaki H, Hisamoto M, Nakatani N. Constituents of Amomum tsao-ko and their radical scavenging and antioxidant activities. Journal of the American Oil Chemists' Society. 2000;77(6):667; doi: https://doi.org/10.1007/s11746-000-0107-4.

31. Yang X, Küenzi P, Plitzko I, Potterat O, Hamburger M. Bicyclononane Aldehydes and Anti proliferative Constituents from Amomum tsao-ko. Planta medica. 2009;75:543-6; doi: 10.1055/s-0029-1185320.

32. Jeon JH, Lee CH, Lee HS. Food Protective Effect of Geraniol and Its Congeners against Stored Food Mites. Journal of Food Protection. 2009;72(7):1468-71; doi: 10.4315/0362-028X-72.7.1468.

33. Takabe K, Katagiri T, Tanaka J. Highly stereoselective syntheses of nerol and geraniol. Chemistry Letters 1977;6:1025-6; doi: 10.1246/cl.1977.1025.

34. Zielińska-Błajet M, Feder-Kubis J. Monoterpenes and Their Derivatives-Recent Development in Biological and Medical Applications. Int J Mol Sci. 2020;21(19):7078; doi: 10.3390/ijms21197078.

35. Dong L, Miettinen K, Goedbloed M, Verstappen F, Voster A, Jongsma M, et al. Characterization of two geraniol synthases from Valeriana officinalis and Lippia dulcis: Similar activity but difference in subcellular localization. Metabolic engineering. 2013;20; doi: 10.1016/j.ymben.2013.09.002.

36. Lapczynski A, Bhatia S, Foxenberg R, Letizia C, Api AM. Fragrance material review on geraniol. Food and chemical toxicology : an international journal published for the British Industrial Biological Research Association. 2008;46 Suppl 11:S160-70; doi: 10.1016/j.fct.2008.06.048.

37. Guimarães A, Quintans J, Quintans-Júnior L. Monoterpenes with Analgesic Activity-A Systematic Review. Phytotherapy research : PTR. 2013;27:1-15; doi: 10.1002/ptr.4686.

38. Medicherla K, Sahu DBD, Kuncha M, Kumar J, Sudhakar G, Sistla R. Oral administration of geraniol ameliorates acute experimental murine colitis by inhibiting pro-inflammatory cytokines and NF-KB signaling. Food Funct. 2015;6; doi: 10.1039/C5F000405E.

39. Solórzano-Santos F, Miranda-Novales M. Essential oils from aromatic herbs as antimicrobial agents. Current opinion in biotechnology. 2011;23:136-41; doi: 10.1016/j.copbio.2011.08.005.

40. Younis N, Abduldaium M, Mohamed M. Protective Effect of Geraniol on Oxidative, Inflammatory and Apoptotic Alterations in Isoproterenol-Induced Cardiotoxicity: Role of the Keap1/Nrf2/HO-1 and PI3K/Akt/mTOR Pathways. Antioxidants. 2020;9:977; doi: 10.3390/antiox9100977.

41. Lei Y, Fu P, Jun X, Cheng P. Pharmacological Properties of Geraniol - A Review. Planta Med. Loading [MathJax]/jax/output/CommonHTML/jax.js 6907.

Page 20/37 
42. Cho M, So I, Chun J, Jeon J-H. The antitumor effects of geraniol: Modulation of cancer hallmark pathways (Review). International Journal of Oncology. 2016;48; doi: 10.3892/ijo.2016.3427.

43. Mączka W, Wińska K, Grabarczyk M. One Hundred Faces of Geraniol. Molecules. 2020;25:3303; doi: 10.3390/molecules25143303.

44. Carnesecchi S, Bras-Gonçalves R, Bradaia A, Zeisel M, Gossé F, Poupon M-F, et al. Geraniol, a component of plant essential oils, modulates DNA synthesis and potentiates 5-fluorouracil efficacy on human colon tumor xenografts. Cancer letters. 2004;215:53-9; doi: 10.1016/j.canlet.2004.06.019.

45. Junior E, Truzzi E, Ferraro L, Fogagnolo M, Pavan B, Beggiato S, et al. Nasal administration of nanoencapsulated geraniol/ursodeoxycholic acid conjugate: Towards a new approach for the management of Parkinson's disease. Journal of Controlled Release. 2020;321; doi:

10.1016/j.jconrel.2020.02.033.

46. Zhang YF, Huang Y, Ni YH, Xu ZM. Systematic elucidation of the mechanism of geraniol via network pharmacology. Drug Des Devel Ther. 2019;13:1069-75; doi: 10.2147/dddt.S189088.

47. Tong X, Xu J, Lian F, Yu X, Zhao Y, Xu L, et al. Structural Alteration of Gut Microbiota during the Amelioration of Human Type 2 Diabetes with Hyperlipidemia by Metformin and a Traditional Chinese Herbal Formula: a Multicenter, Randomized, Open Label Clinical Trial. mBio. 2018;9:e02392-17; doi: 10.1128/mBio.02392-17.

48. Xu X, Gao Z, Yang F, Yang Y, Chen L, Han L, et al. Antidiabetic Effects of Gegen Qinlian Decoction via the Gut Microbiota Are Attributable to Its Key Ingredient Berberine. Genomics, Proteomics \& Bioinformatics. 2020; doi: 10.1016/j.gpb.2019.09.007.

49. Pan G, Liu B, Li S, Han M, Gao L, Xu G, et al. Kuijieling, A Chinese medicine alleviates DSS-induced colitis in C57BL/ $6 \mathrm{~J}$ mouse by improving the diversity and function of gut microbiota. FEMS microbiology letters. 2020;367; doi: 10.1093/femsle/fnaa082.

50. Tang W, Yao X, Xia F, Yang M, Chen Z, Zhou B, et al. Modulation of the Gut Microbiota in Rats by Hugan Qingzhi Tablets during the Treatment of High-Fat-Diet-Induced Nonalcoholic Fatty Liver Disease. Oxidative Medicine and Cellular Longevity. 2018;2018:7261619; doi: 10.1155/2018/7261619.

51. Yu M, Jia H-m, Zhou C, Yang Y, Sun L-L, Zou Z-M. Urinary and Fecal Metabonomics Study of the Protective Effect of Chaihu-Shu-Gan-San on Antibiotic-Induced Gut Microbiota Dysbiosis in Rats. Scientific Reports. 2017;7:46551; doi: 10.1038/srep46551.

52. Xu J, Lian F, Zhao L, Zhao Y, Chen X, Zhang X, et al. Structural modulation of gut microbiota during alleviation of type 2 diabetes with a Chinese herbal formula. The ISME journal. 2014;9; doi: 10.1038/ismej.2014.177.

53. Aiemsaard J, Aiumlamai S, Aromdee C, Taweechaisupapong S, Khunkitti W. The effect of lemongrass oil and its major components on clinical isolate mastitis pathogens and their mechanisms of action on Staphylococcus aureus DMST 4745. Research in Veterinary Science. 2011;91(3):e31-e7; doi: https://doi.org/10.1016/j.rvsc.2011.01.012. 
54. Pilla R, Malvisi M, Snel G, Schwarz D, König S, Czerny C-P, et al. Differential cell count as an alternative method to diagnose dairy cow mastitis. Journal of dairy science. 2013;96; doi: 10.3168/jds.2012-6298.

55. Caporaso JG, Lauber CL, Walters WA, Berg-Lyons D, Lozupone CA, Turnbaugh PJ, et al. Global patterns of $16 \mathrm{~S}$ rRNA diversity at a depth of millions of sequences per sample. Proceedings of the National Academy of Sciences. 2011;108(Supplement 1):4516; doi: 10.1073/pnas.1000080107.

56. Bolyen E, Rideout JR, Dillon M, Bokulich N, Abnet C, Al-Ghalith G, et al. QIIME 2: Reproducible, interactive, scalable, and extensible microbiome data science. 2018.

57. Callahan BJ, McMurdie PJ, Rosen MJ, Han AW, Johnson AJA, Holmes SP. DADA2: High-resolution sample inference from Illumina amplicon data. Nature Methods. 2016;13(7):581-3; doi: $10.1038 /$ nmeth.3869.

58. Katoh K, Misawa K, Kuma K, Miyata T. MAFFT: a novel method for rapid multiple sequence alignment based on fast Fourier transform. Nucleic Acids Res. 2002;30(14):3059-66; doi: 10.1093/nar/gkf436.

59. Price MN, Dehal PS, Arkin AP. FastTree 2 ßC Approximately Maximum-Likelihood Trees for Large Alignments. PLOS ONE. 2012; doi: 10.1371/journal.pone.0009490.

60. Quast C, Pruesse E, Yilmaz P, Gerken J, Schweer T, Yarza P, et al. The SILVA ribosomal RNA gene database project: improved data processing and web-based tools. Nucleic Acids Res. 2013;41(Database issue):D590-6; doi: 10.1093/nar/gks1219.

61. Lozupone C, Knight R. UniFrac: a New Phylogenetic Method for Comparing Microbial Communities. Applied and Environmental Microbiology. 2005;71(12):8228-35; doi: 10.1128/AEM.71.12.82288235.2005.

62. Dasenaki M, Bletsou A, Koulis G, Thomaidis N. Qualitative Multiresidue Screening Method for 143 Veterinary Drugs and Pharmaceuticals in Milk and Fish Tissue Using Liquid Chromatography Quadrupole-Time-of-Flight Mass Spectrometry. Journal of agricultural and food chemistry. 2015;63; doi: 10.1021/acs.jafc.5b00962.

63. -2008 GT. Determination of Streptomycin, Dihydrostrepto-mycin and Kanamycin Residues in Milk and Milk Powder-LC- MS-MS Method.

64. Stiglic G, Watson R, Cilar L. R you ready? Using the R programme for statistical analysis and graphics. Research in Nursing \& Health. 2019;42(6):494-9; doi: https://doi.org/10.1002/nur.21990.

65. Nakajima Y, Mikami O, Yoshioka M, Motoi Y, Ito T, Ishikawa Y, et al. Elevated levels of tumor necrosis factor-alpha (TNF-alpha) and interleukin-6 (IL-6) activities in the sera and milk of cows with naturally occurring coliform mastitis. Res Vet Sci. 1997;62(3):297-8; doi: 10.1016/s0034-5288(97)90209-5.

66. Zhang X, Ding J, Li Y, Song Q, Li S, Hayat M, et al. The changes of inflammatory mediators and vasoactive substances in dairy cows' plasma with pasture-associated laminitis. BMC Veterinary Research. 2020;16; doi: 10.1186/s12917-020-02319-1.

67. Zhao C, Liu G, Li XB, Guan Y, Wang Y, Yuan X, et al. Inflammatory mechanism of Rumenitis in dairy Loading [MathJax]/jax/output/CommonHTML/jax.js MC Veterinary Research. 2018;14; doi: 10.1186/s12917-018- 
1463-7.

68. Ibrahim S, El-Denshary E, Abdallah D. Geraniol, Alone and in Combination with Pioglitazone, Ameliorates Fructose-Induced Metabolic Syndrome in Rats via the Modulation of Both Inflammatory and Oxidative Stress Status. PloS one. 2015;10:e0117516; doi: 10.1371/journal.pone.0117516.

69. Ye C-J, Li S-A, Zhang Y, Lee W-H. Geraniol targets KV1.3 ion channel and exhibits anti-inflammatory activity in vitro and in vivo. Fitoterapia. 2019;139:104394; doi: https://doi.org/10.1016/j.fitote.2019.104394.

70. Bachiega T, Sforcin J. Lemongrass and citral effect on cytokines production by murine macrophages. Journal of ethnopharmacology. 2011;137:909-13; doi: 10.1016/j.jep.2011.07.021.

71. Tan BK, Vanitha J. Immunomodulatory and antimicrobial effects of some traditional Chinese medicinal herbs: a review. Current medicinal chemistry. 2004;11(11):1423-30.

72. Asif M. Antimicrobial potential of Azadirachta indica against pathogenic bacteria and fungi. Journal of Pharmacognosy and phytochemistry. 2012;1(4):78-83.

73. Meng F, Yang S, Wang $X$, Chen T, Wang $X$, Tang $X$, et al. Reclamation of Chinese herb residues using probiotics and evaluation of their beneficial effect on pathogen infection. Journal of Infection and Public Health. 2017;10; doi: 10.1016/j.jiph.2016.11.013.

74. Ma H-D, Deng Y-R, Tian Z, Lian Z-X. Traditional Chinese medicine and immune regulation. Clinical Reviews in Allergy \& Immunology. 2013;44(3):229-41.

75. Shi T, Li T, Jiang X, Jiang X, Zhang Q, Wang Y, et al. Baicalin protects mice from infection with methicillin-resistant Staphylococcus aureus via alleviating inflammatory response. Journal of leukocyte biology. 2020;108; doi: 10.1002/JLB.3AB0820-576RRR.

76. Pan M-H, Chiou Y-S, Tsai M-L, Ho C-T. Anti-inflammatory activity of traditional Chinese medicinal herbs. Journal of traditional and complementary medicine. 2011;1(1):8-24.

77. Cervinkova D, Vlkova H, Borodacova I, Makovcová J, Babak V, Lorencova A, et al. Prevalence of mastitis pathogens in milk from clinically healthy cows. Veterinarni Medicina. 2013;58:567-75; doi: 10.17221/7138-VETMED.

78. Soler L, Dąbrowski R, García N, Alava MA, Lampreave F, Piñeiro M, et al. Acute-phase inter-alphatrypsin inhibitor heavy chain 4 (ITIH4) levels in serum and milk of cows with subclinical mastitis caused by Streptococcus species and coagulase-negative Staphylococcus species. Journal of dairy science. 2019;102(1):539-46.

79. FRANCHESCHINI V, NOGUEIRA M, VICTORIA C, SILVA R, LANGONI H. Research for Mycoplasma spp. in milk samples from mastitic cows. Ars Vet. 2006;22:130-4.

80. Lan XC, Miao XR, Deng-Ji XU, Xiu-Jin HE, Shi P. Research on the anti-endotoxin activity of traditional Chinese medicine in vivo. Journal of Traditional Chinese Veterinary Medicine. 2011.

81. Paliy A, Gujvinska S, Livoshchenko L, Nalivayko L, Livoshchenko YM, Risovaniy V, et al. Specific composition of indigenous microflora (Lactobacillus spp., Bifidobacterium spp., Lactococcus spp.) in farm animals. Ukrainian Journal of Ecology. 2020;10(1). 
82. Markowiak P, Śliżewska K. The role of probiotics, prebiotics and synbiotics in animal nutrition. Gut pathogens. 2018;10(1):1-20.

83. Nagahata $H$, Mukai $T$, Natsume $Y$, Okuda $M$, Ando $T$, Hisaeda $K$, et al. Effects of intramammary infusion of Bifidobacterium breve on mastitis pathogens and somatic cell response in quarters from dairy cows with chronic subclinical mastitis. Animal Science Journal. 2020;91(1):e13406; doi: https://doi.org/10.1111/asj.13406.

84. Nagahata H, Moriyama A, Sawada C, Asai Y, Kokubu C, Gondaira S, et al. Innate immune response of mammary gland induced by intramammary infusion of Bifidobacterium breve in lactating dairy cows. Journal of Veterinary Medical Science. 2020:20-0273.

85. Xu H, Huang W, Hou Q, Kwok L-y, Sun Z, Ma H, et al. The effects of probiotics administration on the milk production, milk components and fecal bacteria microbiota of dairy cows. Science Bulletin. 2017;62(11):767-74; doi: https://doi.org/10.1016/j.scib.2017.04.019.

86. Nurdin E, Amelia T, Makin M. The effects of herbs on milk yield and milk quality of mastitis dairy cow. Journal of the Indonesian Tropical Animal Agriculture. 2011;36(2):104-8.

87. Pol M, Ruegg PL. Treatment practices and quantification of antimicrobial drug usage in conventional and organic dairy farms in Wisconsin. J Dairy Sci. 2007;90(1):249-61; doi: 10.3168/jds.S00220302(07)72626-7.

88. Ji S, Jiang T, Yan H, Guo C, Liu J, Su H, et al. Ecological Restoration of Antibiotic-Disturbed Gastrointestinal Microbiota in Foregut and Hindgut of Cows. Frontiers in Cellular and Infection Microbiology. 2018;8; doi: 10.3389/fcimb.2018.00079.

89. Schwarzer M, Strigini M, Leulier F. Gut Microbiota and Host Juvenile Growth. Calcif Tissue Int. 2018;102(4):387-405; doi: 10.1007/s00223-017-0368-y.

90. Savage, C D. Microbial Ecology of the Gastrointestinal Tract. Annual Review of Microbiology. 1977;31(1):107-33.

91. Round JL, Mazmanian SK. The gut microbiota shapes intestinal immune responses during health and disease. Nature Reviews Immunology. 2009;9(8):600-; doi: 10.1038/nri2614.

92. Pereira R, Carroll L, Lima S, Foditsch C, Siler J, Bicalho R, et al. Impacts of feeding preweaned calves milk containing drug residues on the functional profile of the fecal microbiota. Scientific Reports. 2018;8; doi: 10.1038/s41598-017-19021-2.

93. Jones G. On-farm Tests for Drug Residues in Milk. Virginia Cooperative Extension Service 1999:4014.

94. Sachi S, Ferdous J, Sikder MH, Hussani SAK. Antibiotic residues in milk: Past, present, and future. Journal of advanced veterinary and animal research. 2019;6(3):315.

95. Jayalakshmi K, Paramasivam M, Sasikala M, Tamilam T, Sumithra A. Review on antibiotic residues in animal products and its impact on environments and human health. J Entomol Zool Stud. 2017;5(3):1446-51.

96. Rodriguez-Garcia A, Hosseini S, Martinez-Chapa So, Cordell GA. Multi-target activities of selected Loading [MathJax]/jax/output/CommonHTML/jax.js in Organic Chemistry. 2017;14(4):272-9. 


\section{Tables}

Table 1. Residue of cephalexin and kanamycin in milk of dairy cows after stopping therapy.

Days after stopping the drug

\begin{tabular}{|c|c|c|c|c|c|c|c|}
\hline Cow ID & Day 1 & Day 2 & Day 3 & Day 4 & Day 5 & Day 6 & Day 7 \\
\hline CA_1 & $+/ *$ & $+/ *$ & $+/ *$ & $+/ *$ & $+/ *$ & $+/ *$ & $+/ *$ \\
\hline CA_2 & $+/ *$ & $+/ *$ & $+/ *$ & $+/ *$ & $+/ *$ & $+/ *$ & $+/ *$ \\
\hline CA_3 & $+/ *$ & $+/ *$ & $+/ *$ & $+/ *$ & $+/ *$ & $+/ *$ & $+/ *$ \\
\hline CA_4 & $+/ *$ & $+/ *$ & $+/ *$ & $+/ *$ & $+/ *$ & $+/ *$ & $+/ *$ \\
\hline CA_5 & $+/ *$ & $+/ *$ & $+/ *$ & $+/ *$ & $+/ *$ & $+/ *$ & $+/ *$ \\
\hline CA_6 & $+/ *$ & $+/ *$ & $+/ *$ & $+/ *$ & $+/ *$ & $+/ *$ & $+/ *$ \\
\hline CA_7 & $+/ *$ & $+/ *$ & $+/ *$ & $+/ *$ & $+/ *$ & $+/ *$ & $+/ *$ \\
\hline CA_8 & $+/ *$ & $+/ *$ & $+/ *$ & $+/ *$ & $+/ *$ & $+/ *$ & $+/ *$ \\
\hline CA_9 & $+/ *$ & $+/ *$ & $+/ *$ & $+/ *$ & $+/ *$ & $+/ *$ & $+/ *$ \\
\hline CA_10 & $+/ *$ & $+/ *$ & $+/ *$ & $+/ *$ & $+/ *$ & $+/ *$ & $+/ *$ \\
\hline
\end{tabular}

" + " means that the residue of cephalexin can be detected in milk; " " means that the residue of kanamycin be detected in milk.

Table 2. Residue of geraniol in milk of dairy cows after stopping therapy. 


\begin{tabular}{llllllll} 
& Day 1 & Day 2 & Day 3 & Day 4 & Day 5 & Day 6 & Day 7 \\
\hline CG_1 & + & + & + & - & - & - & - \\
\hline CG_2 & + & + & + & + & - & - & - \\
\hline CG_3 & + & + & + & - & - & - & - \\
\hline CG_4 & + & + & + & - & - & - & - \\
\hline CG_5 & - & - & - & - & - & - & - \\
\hline CG_6 & + & + & + & - & - & - & - \\
\hline CG_7 & + & + & + & - & - & - & - \\
\hline CG_8 & + & - & - & - & - & - & - \\
\hline CG_9 & + & - & - & - & - & - & - \\
\hline CG_10 + & - & - & - & - & - & -
\end{tabular}

" + " means that the residue of geraniol can be detected in milk; "-" means that the residue of geraniol cannot be detected in milk.

Figures 
A
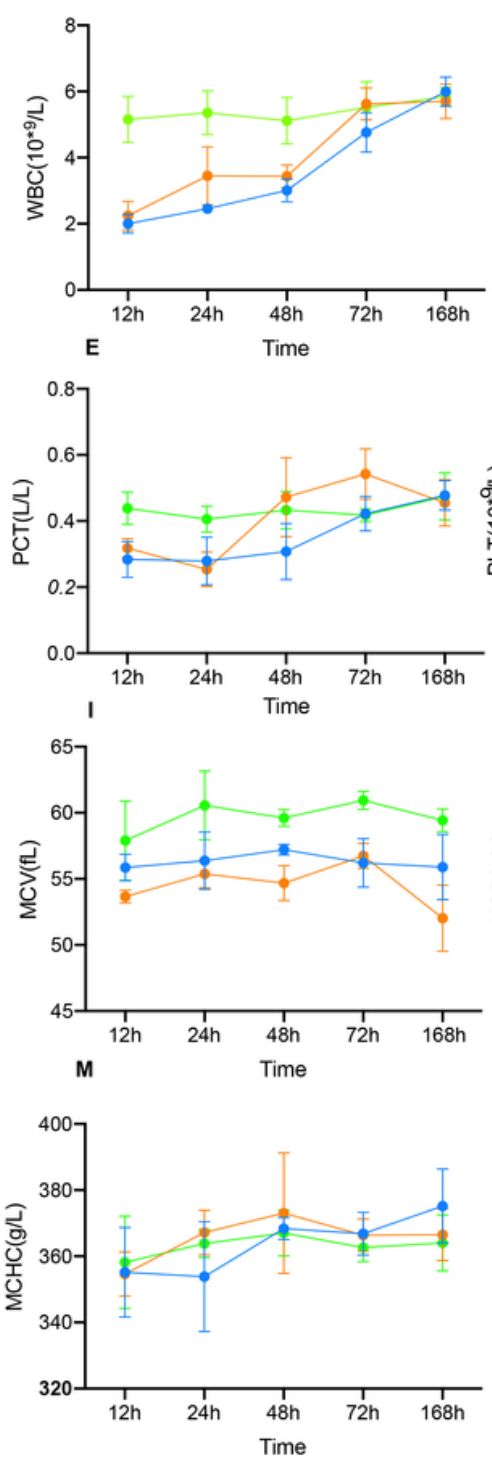

B
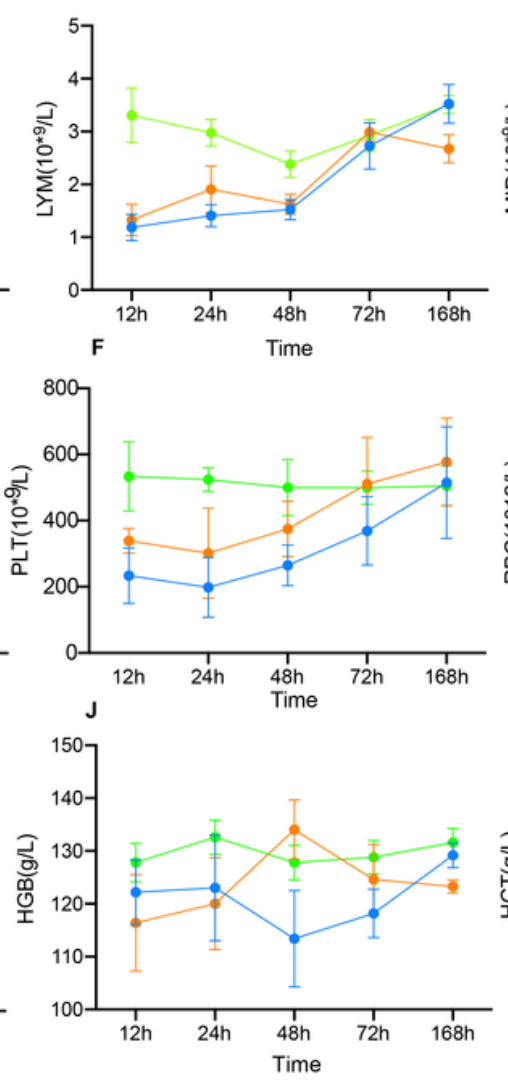

- Geraniol treatment

- Antibiotic treatment

- Control
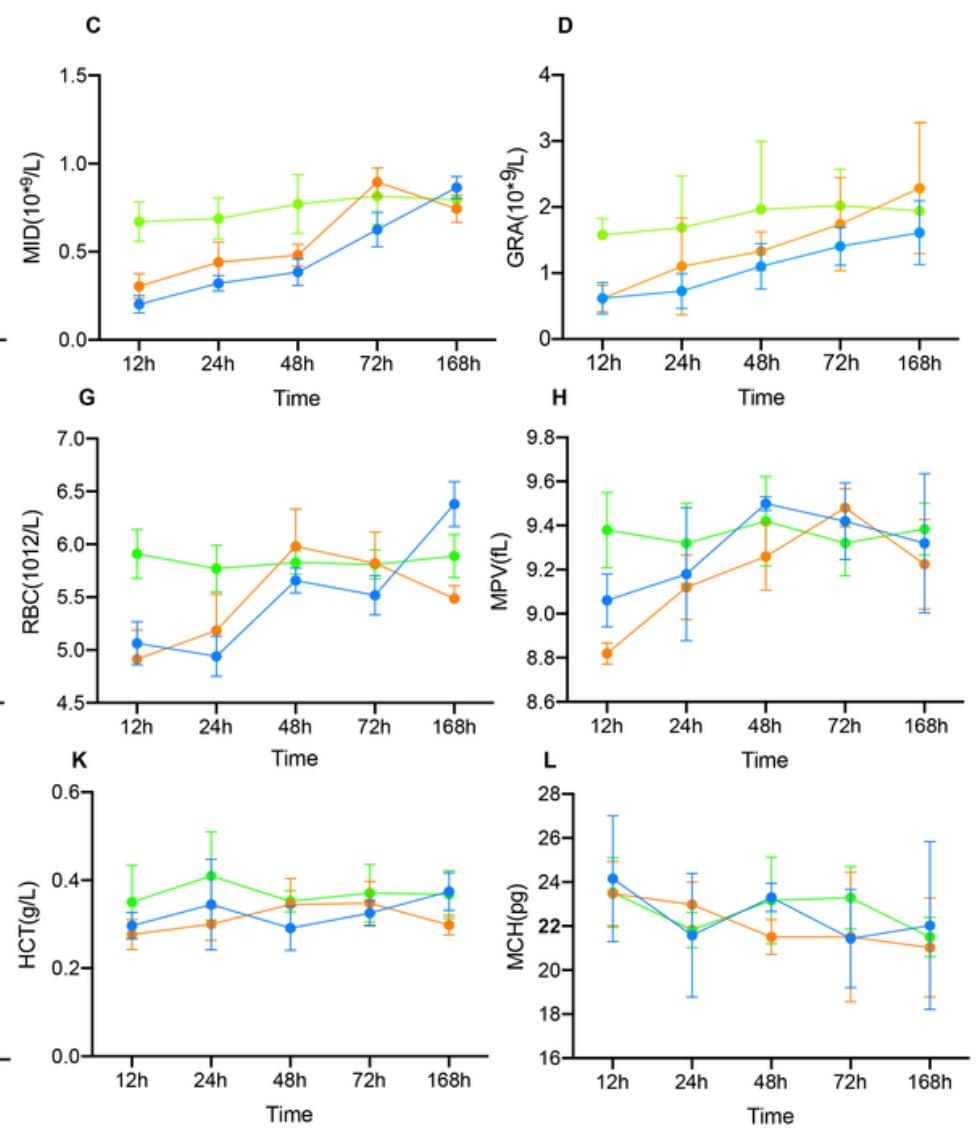

\section{Figure 1}

Effect of geraniol and antibiotics on the recovery of Blood Routine Indexes in mice with bacterial infection. (A) white blood cell count (WBC); (B) absolute lymphocyte value (LYM); (C) absolute intermediate cell (MID); (D) absolute granulocyte value (GRA); (E) platelet packed volume (PCT); (F) platelet count (PLT); (G) red blood cell count (RBC); (H) average platelet volume (MPV); (I) mean red blood cell volume (MCV); (J) hemoglobin (HGB); (K) hematocrit (HCT); (L) mean hemoglobin content $(\mathrm{MCH}) ;(\mathrm{M})$ mean hemoglobin concentration $(\mathrm{MHCH})$. h means hours; $d$ means day. 

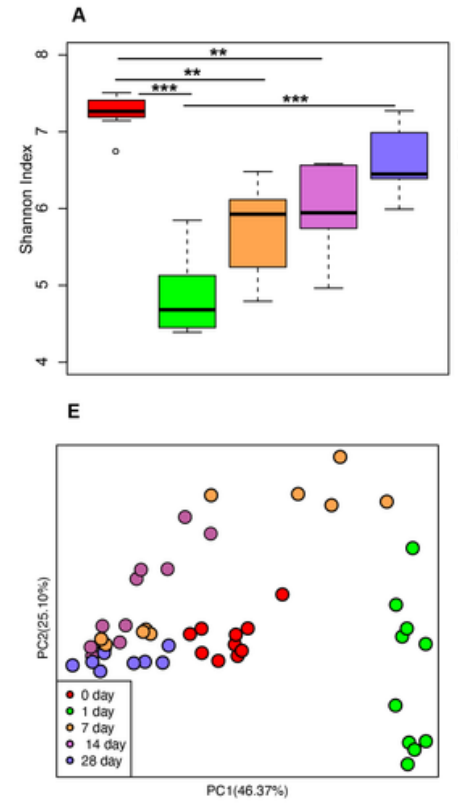
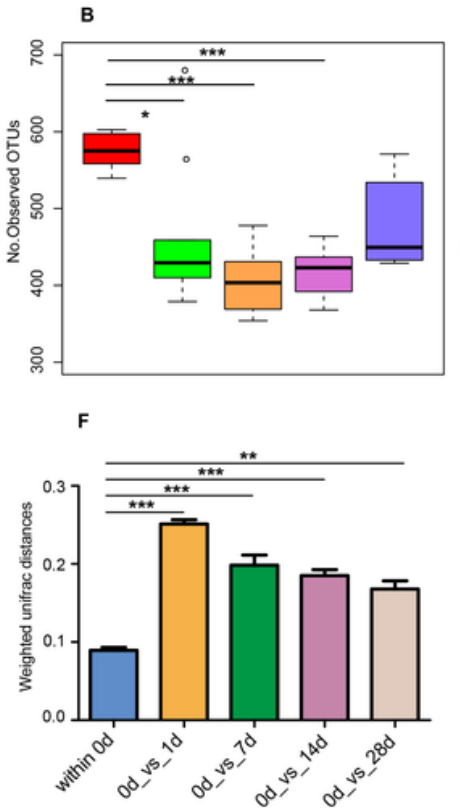

c

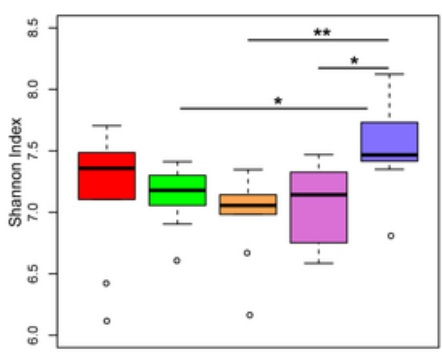

G

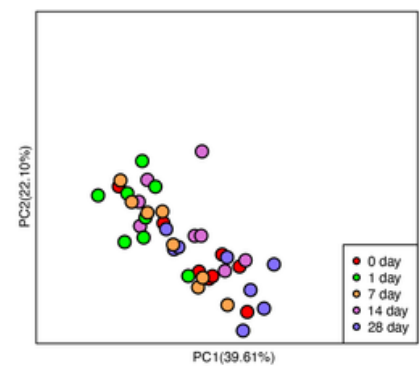

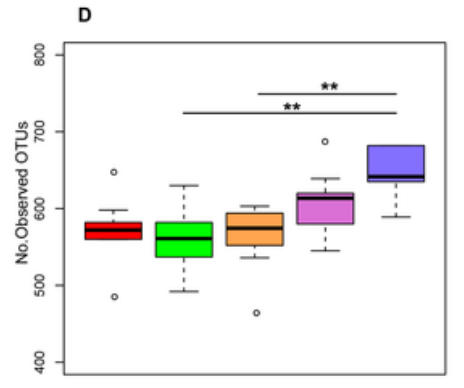

口 0 day ㅁay 미 day 口28 day

\section{Figure 2}

Dynamic changes of alpha and beta diversity of gut microbiotas in Escherichia coli (LD50) infection model mice treated with antibiotics and geraniol. Shannon index (A) and number of observe OTUs (B) of gut microbiotas in bacterial infection model mice treated with antibiotics; Shannon index (C) and number of observe OTUs (D) of gut microbiotas in bacterial infection model mice treated with geraniol; Principal coordinate analysis (PCOA) based on Weighted Unifrac distance in antibiotic treatment group (E) and geraniol treatment group (G); Dynamic changes of phylogenetic distance of gut microbiotas of mice after administration of antibiotics $(\mathrm{F}) /$ geraniol $(\mathrm{H})$ and before administration. 0th day indicates that the mice are infected with E. coli and have not been treated with drugs; 1 st day means 1 day after injection drug; 5th day means 5 day after continuous injection drug, and stopping administration; 14th and 28th day mean 14, 28 day after administration, separately. ( $p$ values calculated by the Kruskal-Wallis test followed by post-hoc Dunn's multiple comparisons test: $*<0.05, * *<0.01$ and $* * *<0.001$ ) 

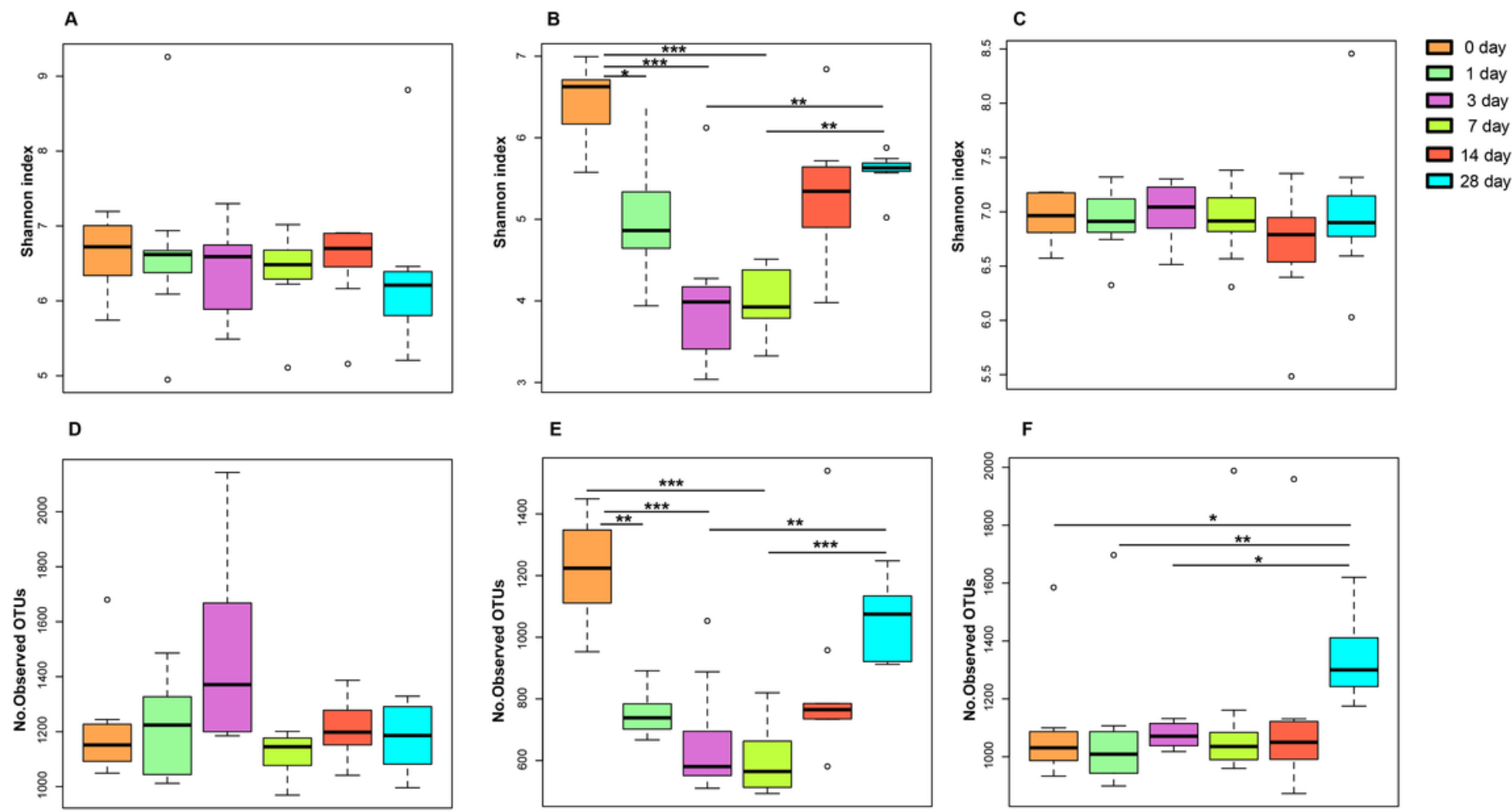

G
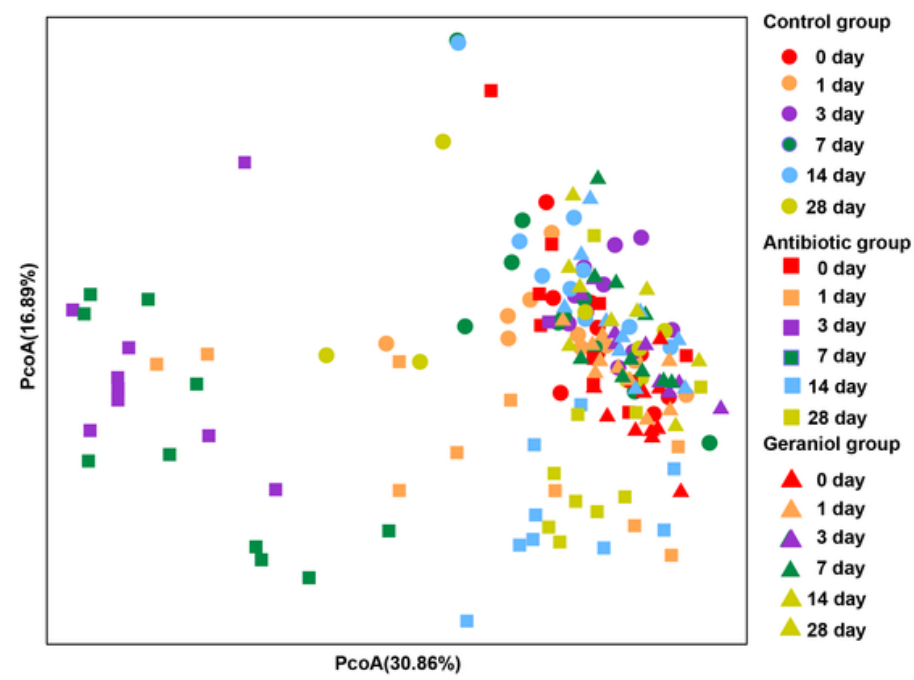

Figure 3

Dynamic changes of alpha and beta diversity of gut microbiotas in mice fed with saline, antibiotics and geraniol. Shannon index of gut microbiotas in mice fed with saline (A), antibiotics (B) and geraniol (C); Number of observed OTUs of gut microbiotas in mice fed with saline (D), antibiotics (E) and geraniol (F); (G) Principal coordinate analysis (PCoA) based on Weighted Unifrac distance of gut microbiotas in mice after being fed with saline, antibiotics and geraniol, separately. 0th means before the mice were fed with the drug; 1 th day means 1 day after oral administration; 3th day means 3 day after continuous oral administration, and stopping oral administration; 7th, 14th and 28th day mean 7, 14, 28 day after oral administration, separately. ( $p$ values calculated by the Kruskal-Wallis test followed by post-hoc Dunn's multiple comparisons test: $*<0.05 . * *<0.01$ and $* * *<0.001$ ) 

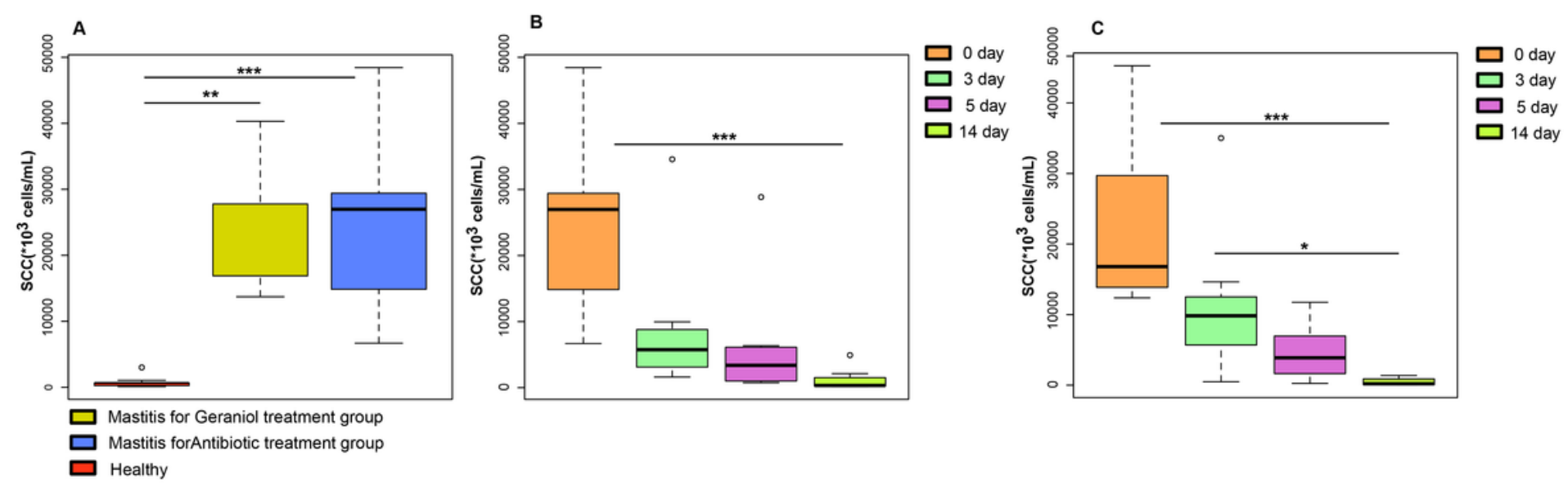

Figure 4

The number of somatic cells in the milk of cows. $\triangle A \otimes C o m p a r i s o n$ of the number of somatic cells in milk between healthy and cows with mastitis; Dynamic changes of somatic cells in dairy cows with mastitis treated with antibiotics $(B)$ and geraniol $(C)$. ( $p$ values calculated by the Kruskal-Wallis test followed by post-hoc Dunn's multiple comparisons test: $*<0.05, * *<0.01$ and $* * *<0.001$ )
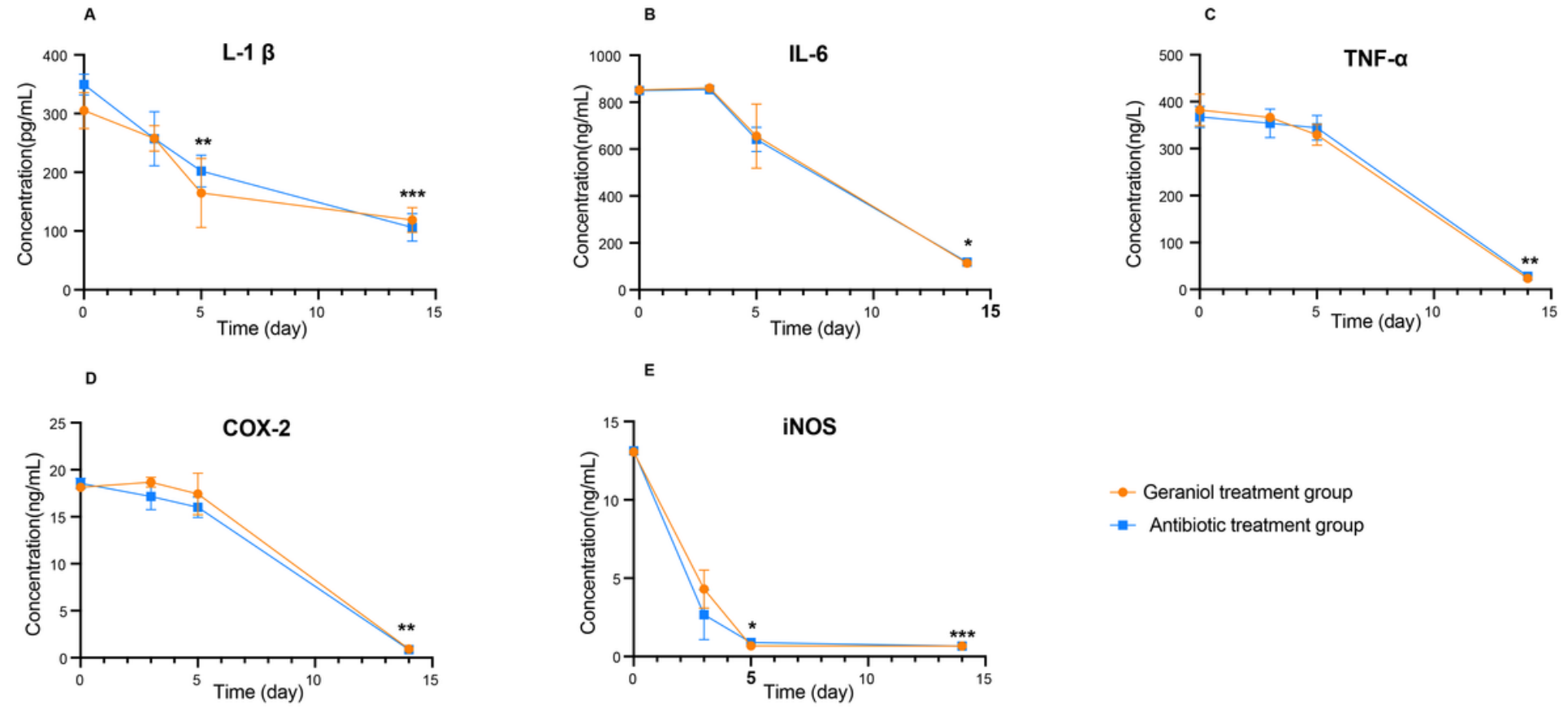

Figure 5

Dynamic changes of serum inflammatory factors in dairy cows with mastitis treated with antibiotics and geraniol. (A) Nterleukin-6; (B) Interleukin-1 $\beta$; (C)Tumor necrosis factor-a; (D) Cyclooxygenase-2 and (E) Inducible nitric oxide synthase. ( $\mathrm{p}$ values (compare with day 0 ) calculated by Mann-Whitney $\mathrm{U}: *<0.05$, $* *<0.01$, and $* * *<0.001)$ 
A

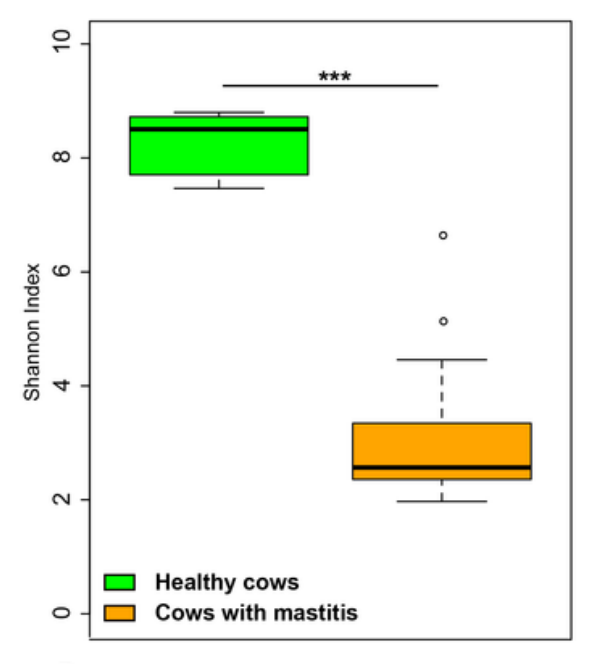

D

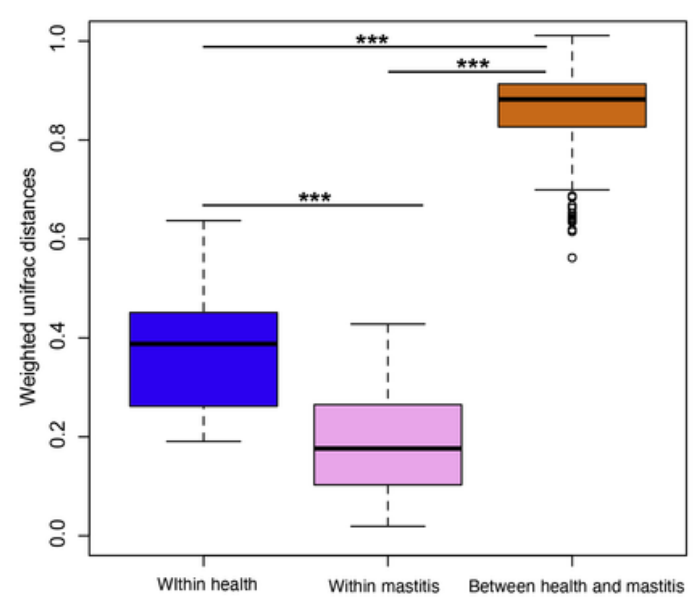

B

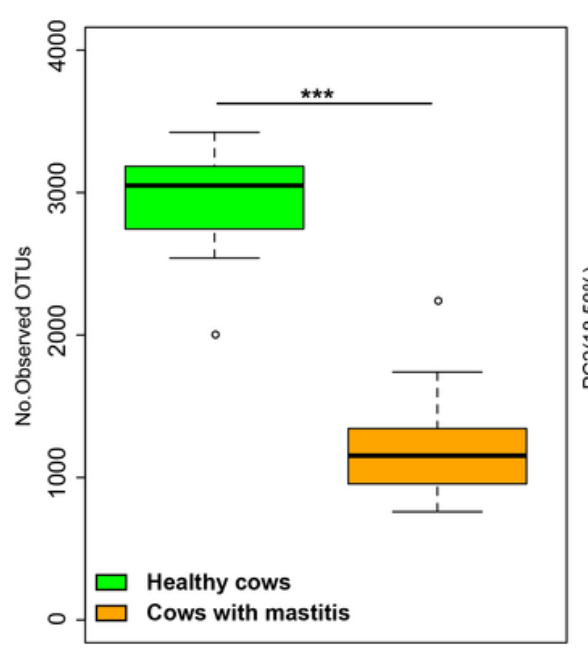

E c

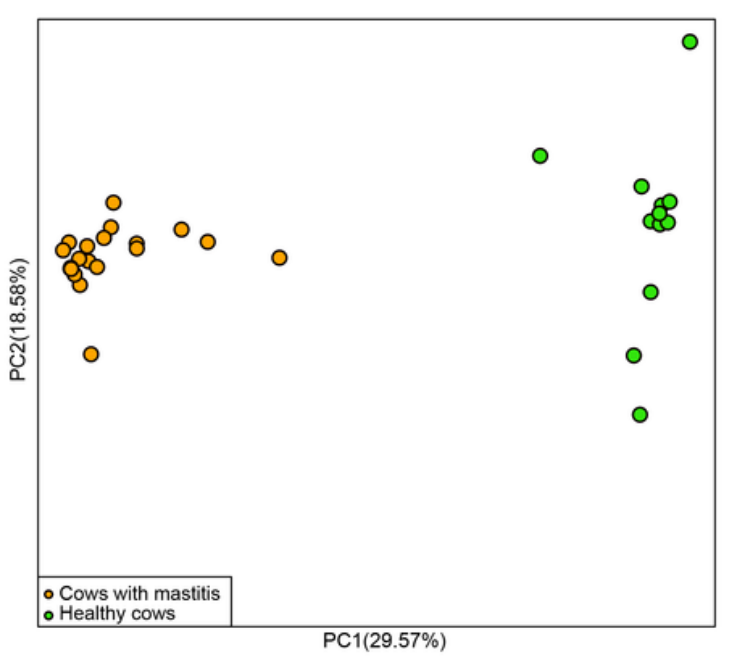

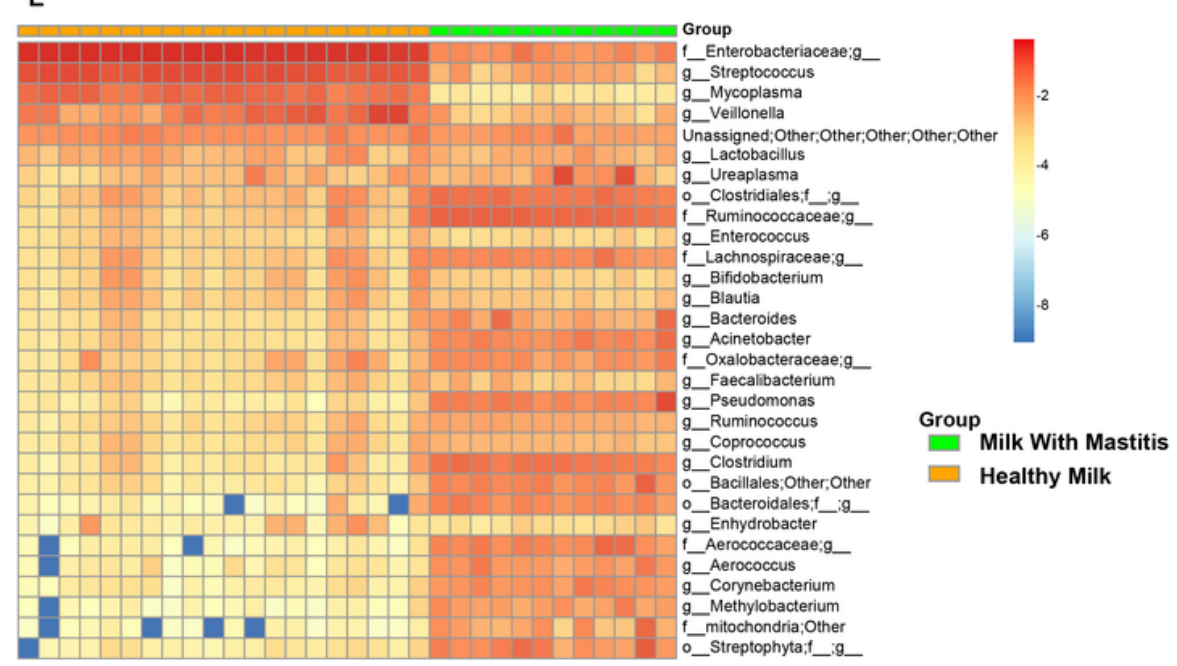

Figure 6

Comparison of the composition of milk bacteria between dairy cows with mastitis and healthy cows. (A) Shannon index and (B) Number of observed OTUs of milk microbiotas in dairy cows with mastitis and healthy cows; (C) Principal coordinate analysis (PCOA) based on Weighted Unifrac distance of milk microbiotas in dairy cows with mastitis and healthy cows; (D) Interindividual variations were determined by average weighted UniFrac distances between individuals in milk microbiotas of dairy cows with mastitis and healthy cows, respectively, while between-group variations were determined by distances between cows with mastitis and healthy cows. (E) Heatmap of top 30 most abundance genera in milk of cows with mastitis and healthy cows. $(* * *$ means $p<0.001 ; p$ values calculated by Mann-Whitney $U$ in $A$ and $B ; p$ values calculated by the Kruskal-Wallis test followed by post-hoc Dunn's multiple comparisons test in D) 


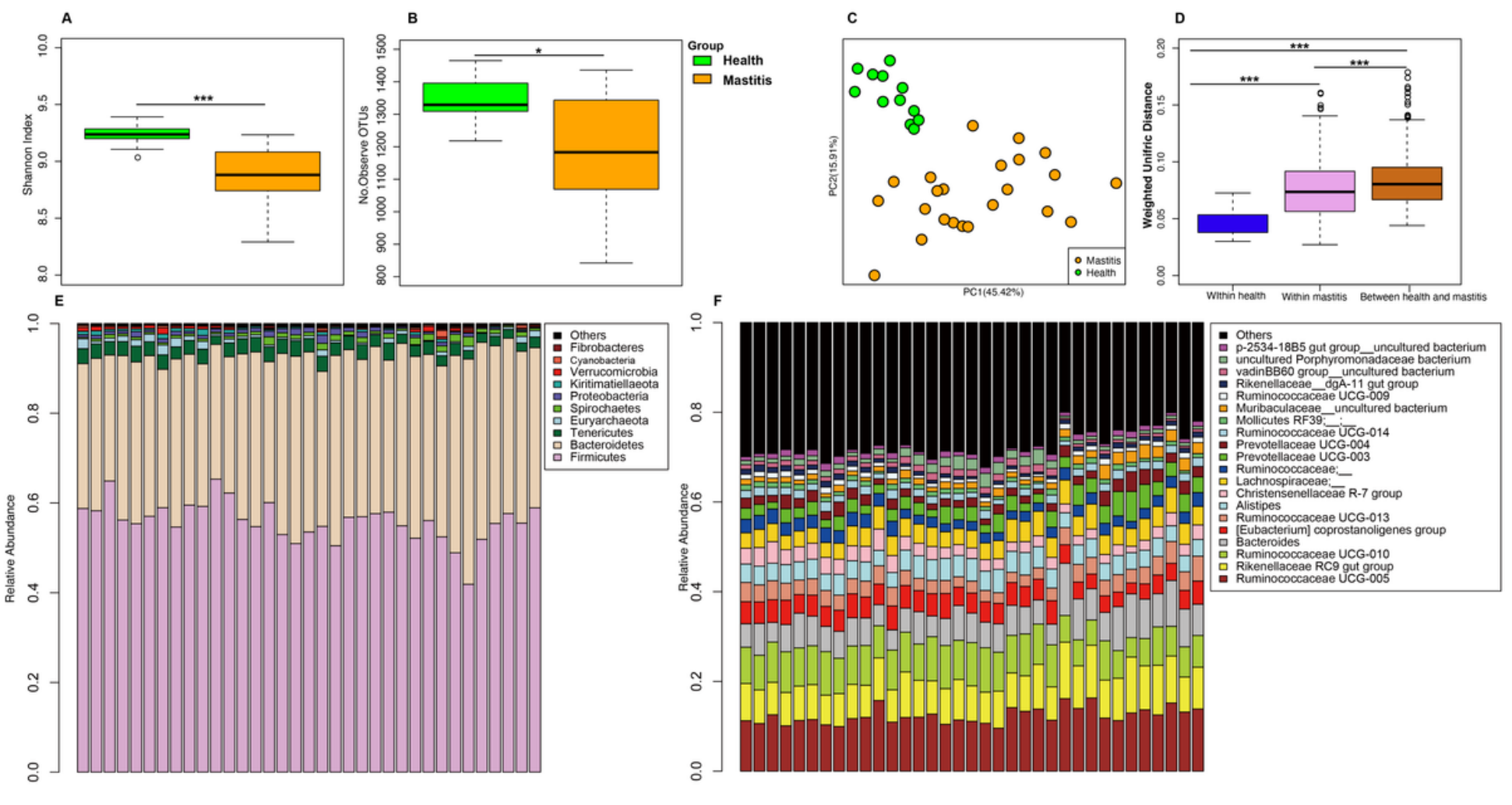

Figure 7

Comparison of the composition of gut microbiome between dairy cows with mastitis and healthy cows. (A) Shannon index and (B) Number of observed OTUs of gut microbiotas in dairy cows with mastitis and healthy cows; (C) Principal coordinate analysis (PCOA) based on Weighted Unifrac distance of gut microbiotas in dairy cows with mastitis and healthy cows; (D) Interindividual variations were determined by average weighted UniFrac distances between individuals in gut microbiotas of dairy cows with mastitis and healthy cows, respectively, while between-group variations were determined by distances between cows with mastitis and healthy cows. Stacked bar plots illustrate the mean relative abundance of OTUs at the phylum (E, top 10) and genus (F, top 20) level in the fecal of dairy cows with mastitis and healthy cows. ( $*<0.05, * * *<0.001$; $p$ values calculated by Mann-Whitney $\mathrm{U}$ in $\mathrm{A}$ and $\mathrm{B} ; \mathrm{p}$ values calculated by the Kruskal-Wallis test followed by post-hoc Dunn's multiple comparisons test in $D$ ) 


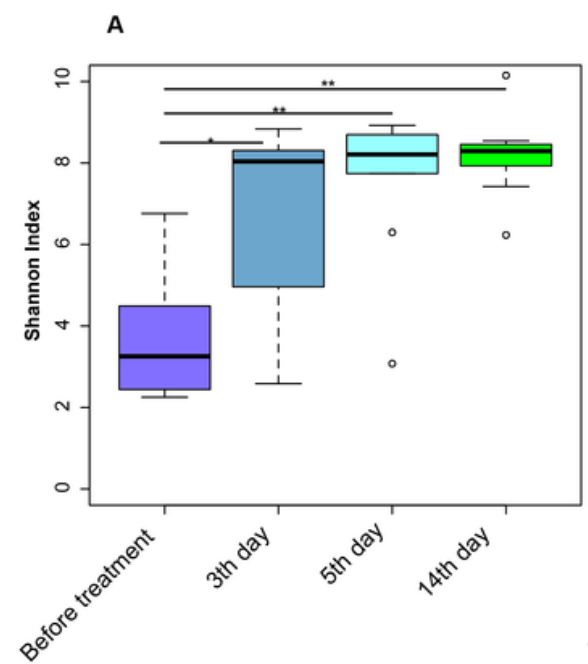

C
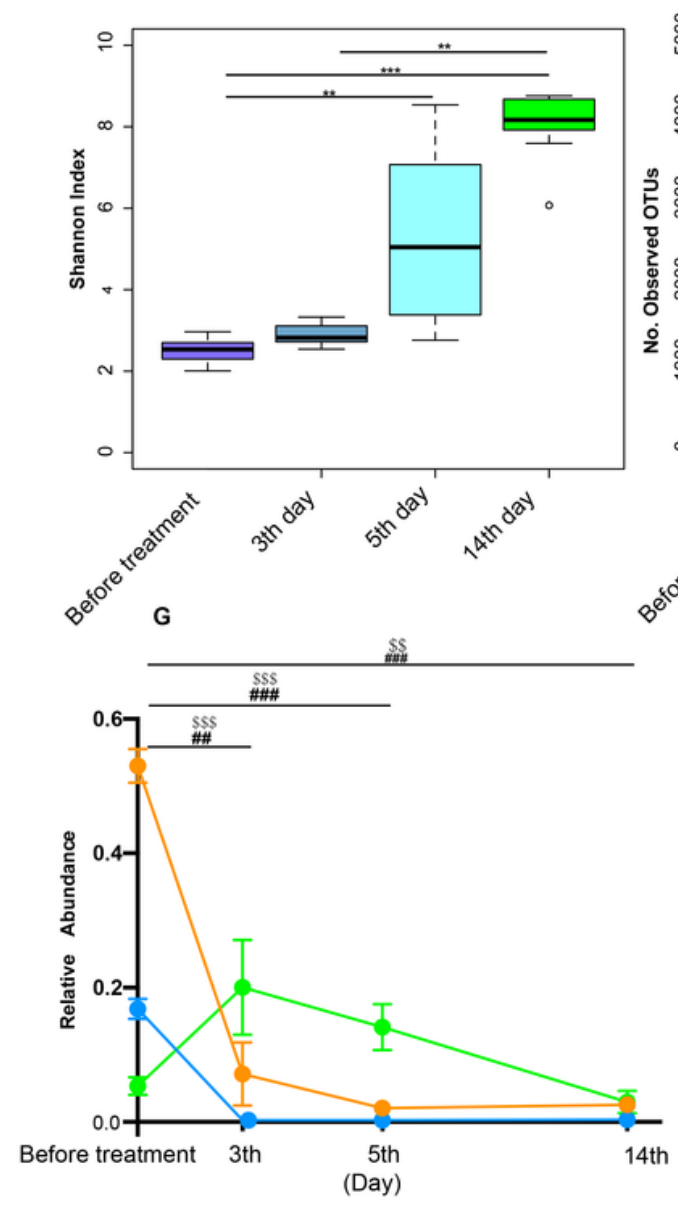

B

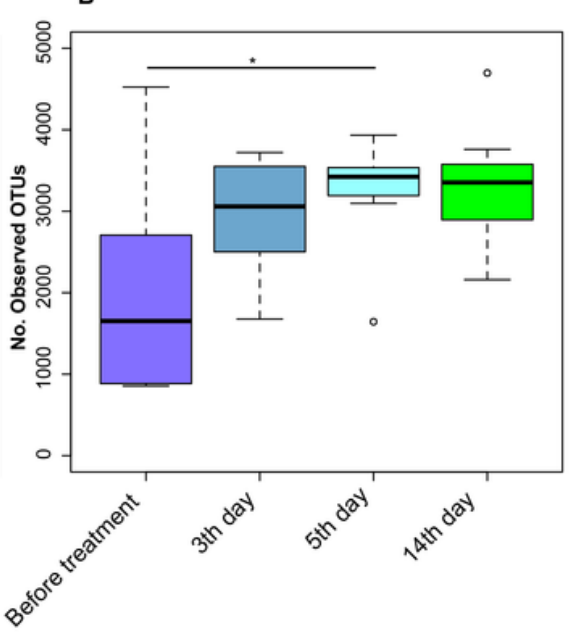

D

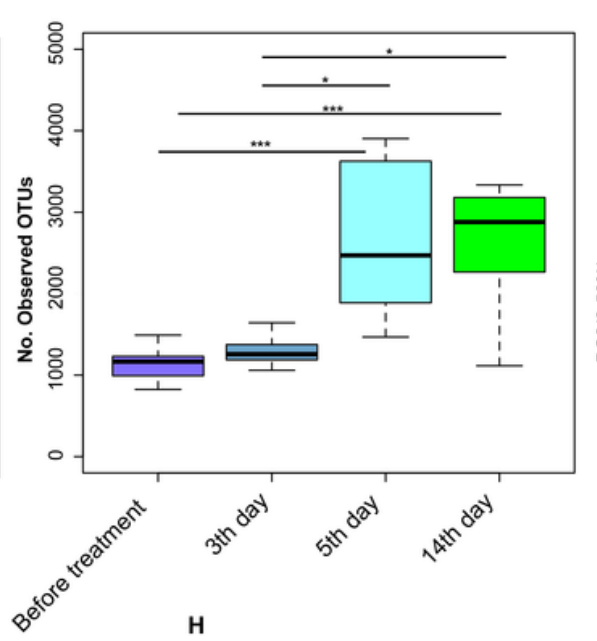

H

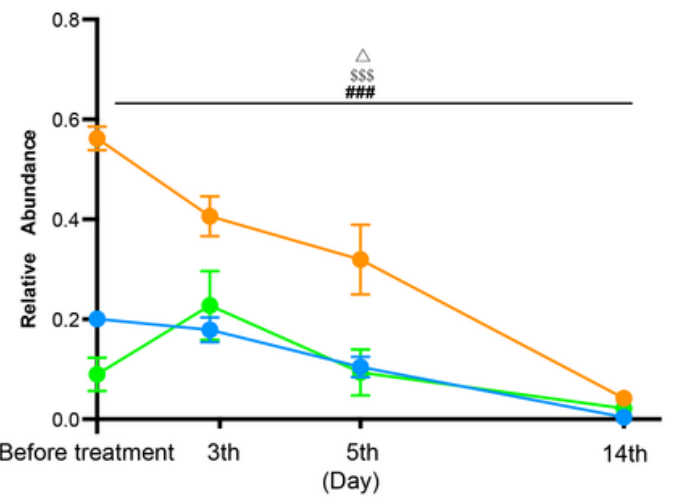

E

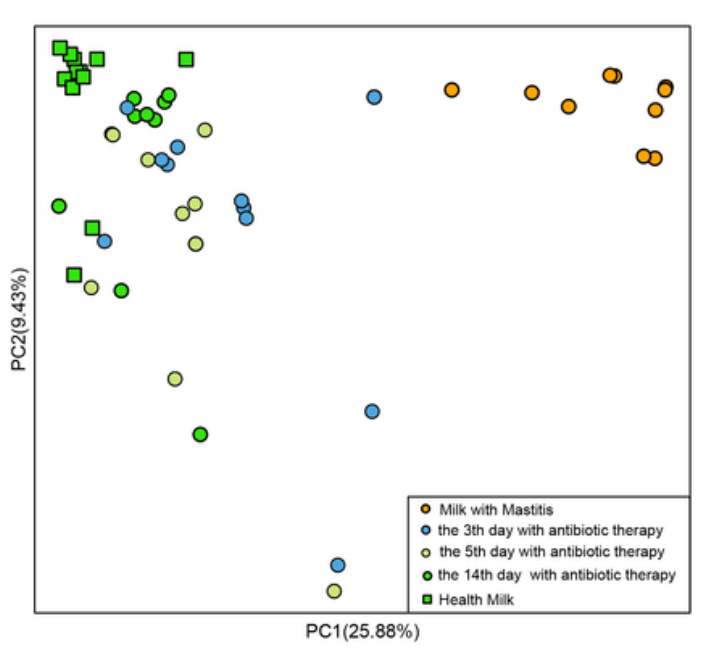

F

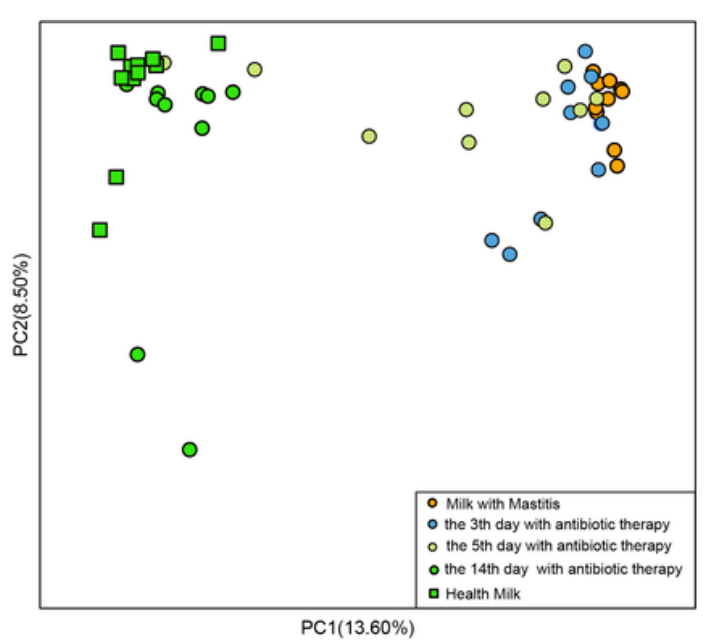

- Enterobacteriaceae

- Streptococcus

- Mycoplasma

\section{Figure 8}

Effect of antibiotic and geraniol on milk microbiotas of dairy cows in the treatment of mastitis. Dynamic changes of (A) Shannon index and (B) Number of observed OTUs of milk microbiotas in dairy cows treated with antibiotics; Dynamic changes of (C) Shannon index and (D) Number of observed OTUs of milk microbiotas in dairy cows treated with geraniol; Dynamic cluster of bacteria in milk of dairy cows with mastitis supported by Principal component analysis based on Weighted Unifrac distance before and aftar wcinn antihintin (E) and noraninl (E). Dynamic changes of relative abundance of pathogens Loading [MathJax]/jax/output/CommonHTML/jax.js 
(Enterobacteriaceae, Streptococcus and Mycoplasma) in milk of dairy cows with mastitis after antibiotic $(\mathrm{G})$ and geraniol $(\mathrm{H})$ treatment. $3 \mathrm{~d}$ and $5 \mathrm{~d}$ means after continuous administration for three and five days, separately; $14 \mathrm{~d}$ means the 14 th days after receiving drug treatment (It also means the 9th day after stopping drug treatment). ( $p$ values calculated by the Kruskal-Wallis test followed by post-hoc Dunn's multiple comparisons test: $*<0.05, * *<0.01$ and $* * *<0.001$ for Shannon index and Number of observed OTUs in (A), (B), (C) and (D); \#\# $<0.01$ and \#\#\# $<0.001$ for Enterobacteriaceae in (G) and (H);

$$
<0.01 \text { and }
$$

$\$<0.001$ for Streptococcus in $(\mathrm{G})$ and $(\mathrm{H}),<0.05$ for Mycoplasma in $(\mathrm{H}))$

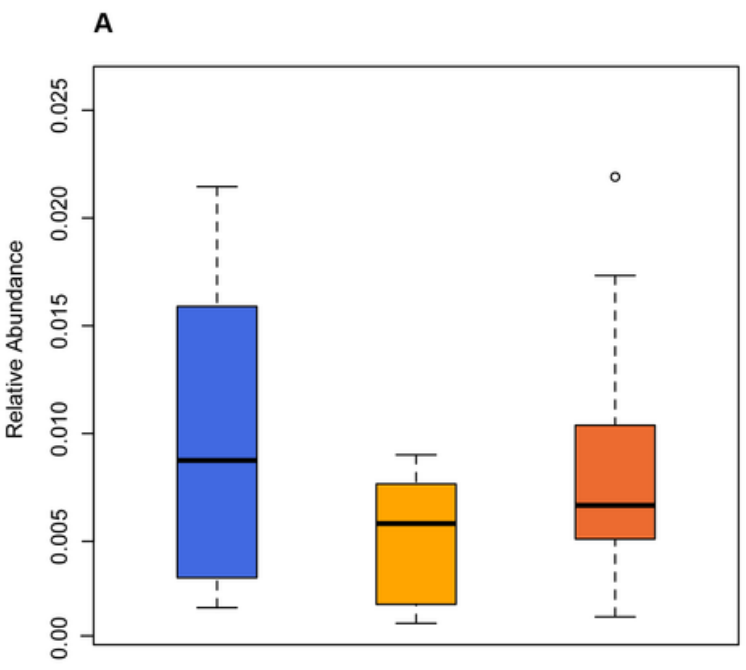

C

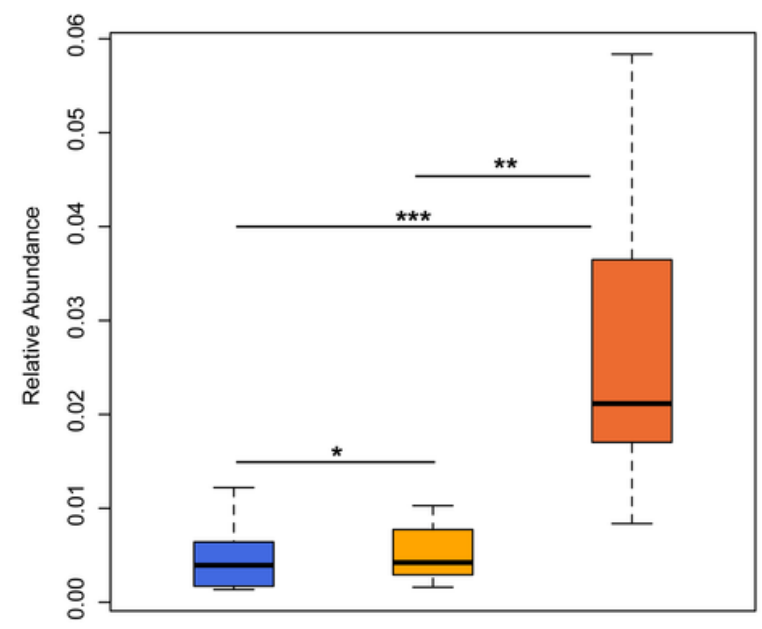

B

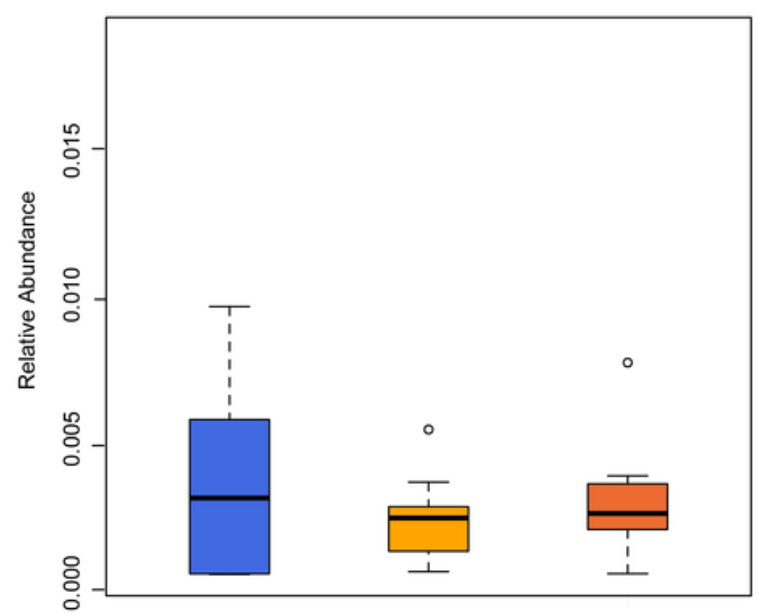

D

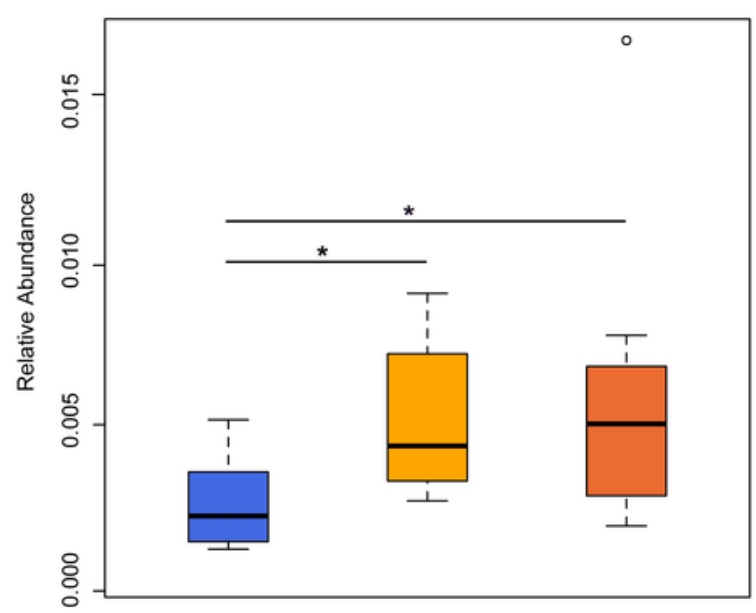

Figure 9

Dynamic changes of relative abundance of probiotics in milk during the treatment of cow mastitis with antibiotics and geraniol. Dynamic changes of relative abundance of Lactobacillus (A) and Bifidobacterium (B) in the antibiotic treatment group; Dynamic changes of relative abundance of Lactobacillus (C) and Bifidobacterium (D) in the geraniol treatment group. $3 \mathrm{~d}$ and $5 \mathrm{~d}$ means after continuous administration for three and five days, separately. ( $p$ values calculated by the Kruskal-Wallis 

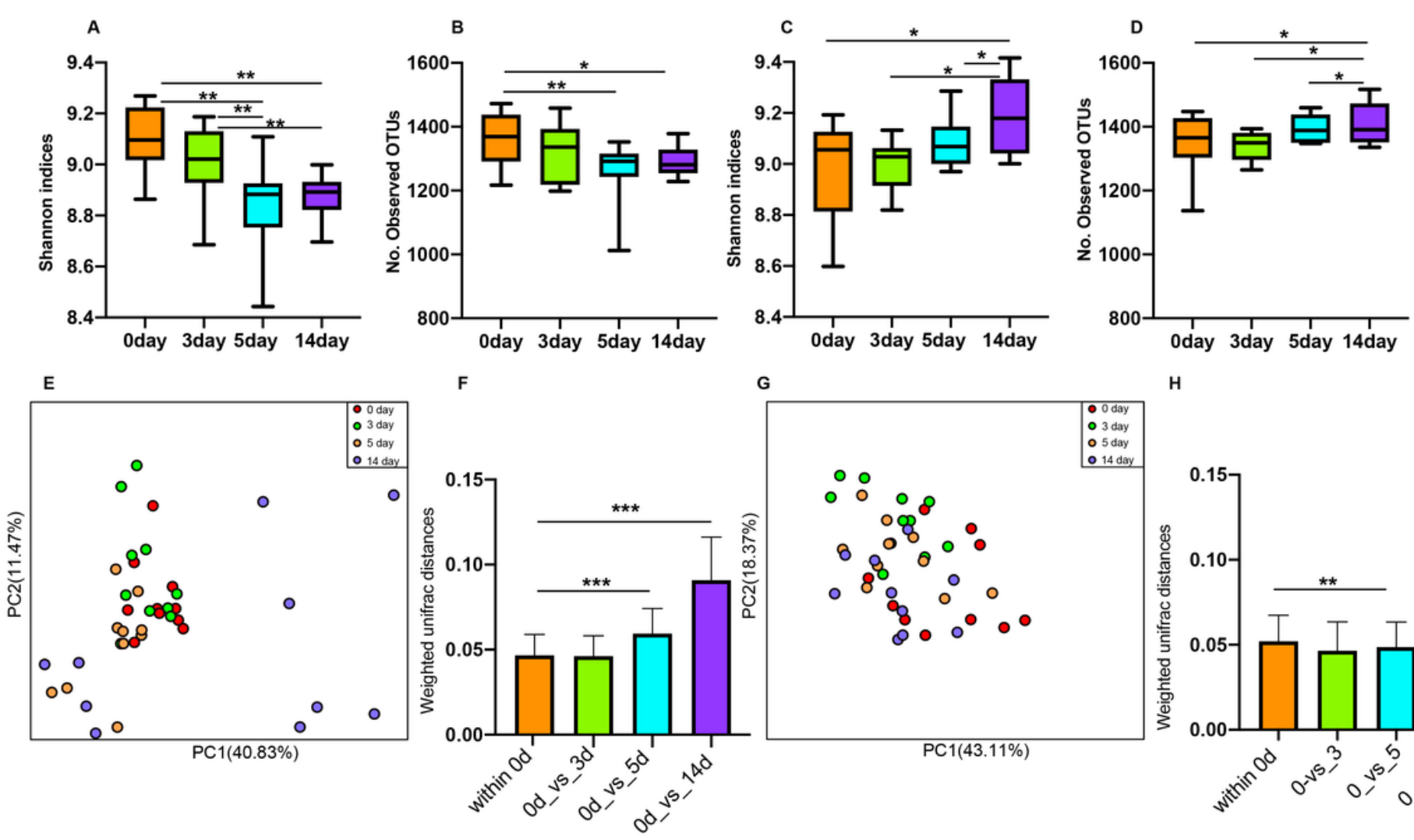

H

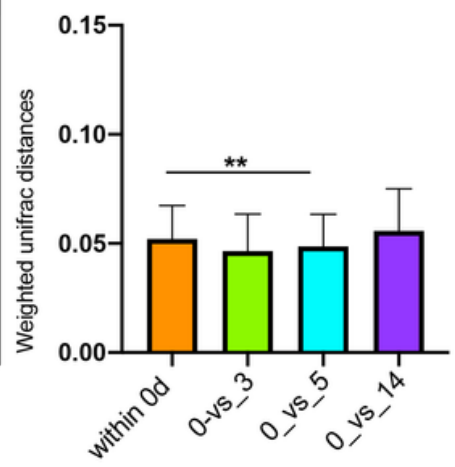

Figure 10

Effect of antibiotic and geraniol on gut microbiotas of dairy cows in the treatment of mastitis. Dynamic changes of (A) Shannon index and (B) Number of observed OTUs of gut microbiotas in dairy cows treated with antibiotics; Dynamic changes of (C) Shannon index and (D) Number of observed OTUs of gut microbiotas in dairy cows treated with geraniol; Dynamic cluster of bacteria in milk of dairy cows with mastitis supported by Principal component analysis based on Weighted Unifrac distance before and after using antibiotic (E) and geraniol (G); Phylogenetic distance of gut microbiotas in cows after administration of antibiotics $(\mathrm{F}) /$ geraniol $(\mathrm{H})$ and before administration. 0th day indicates that the cows with mastitis have not been treated with drugs; 1 st day means 1 day after a receiving drug treatment; $3 \mathrm{~d}$ and $5 \mathrm{~d}$ means after continuous administration for three and five days, separately; $14 \mathrm{~d}$ means the 14 th days after receiving drug treatment (It also means the 9th day after stopping drug treatment). ( $p$ values calculated by the Kruskal-Wallis test followed by post-hoc Dunn's multiple comparisons test: $*<0.05, * *$ $<0.01$ and $* * *<0.001$ ) 

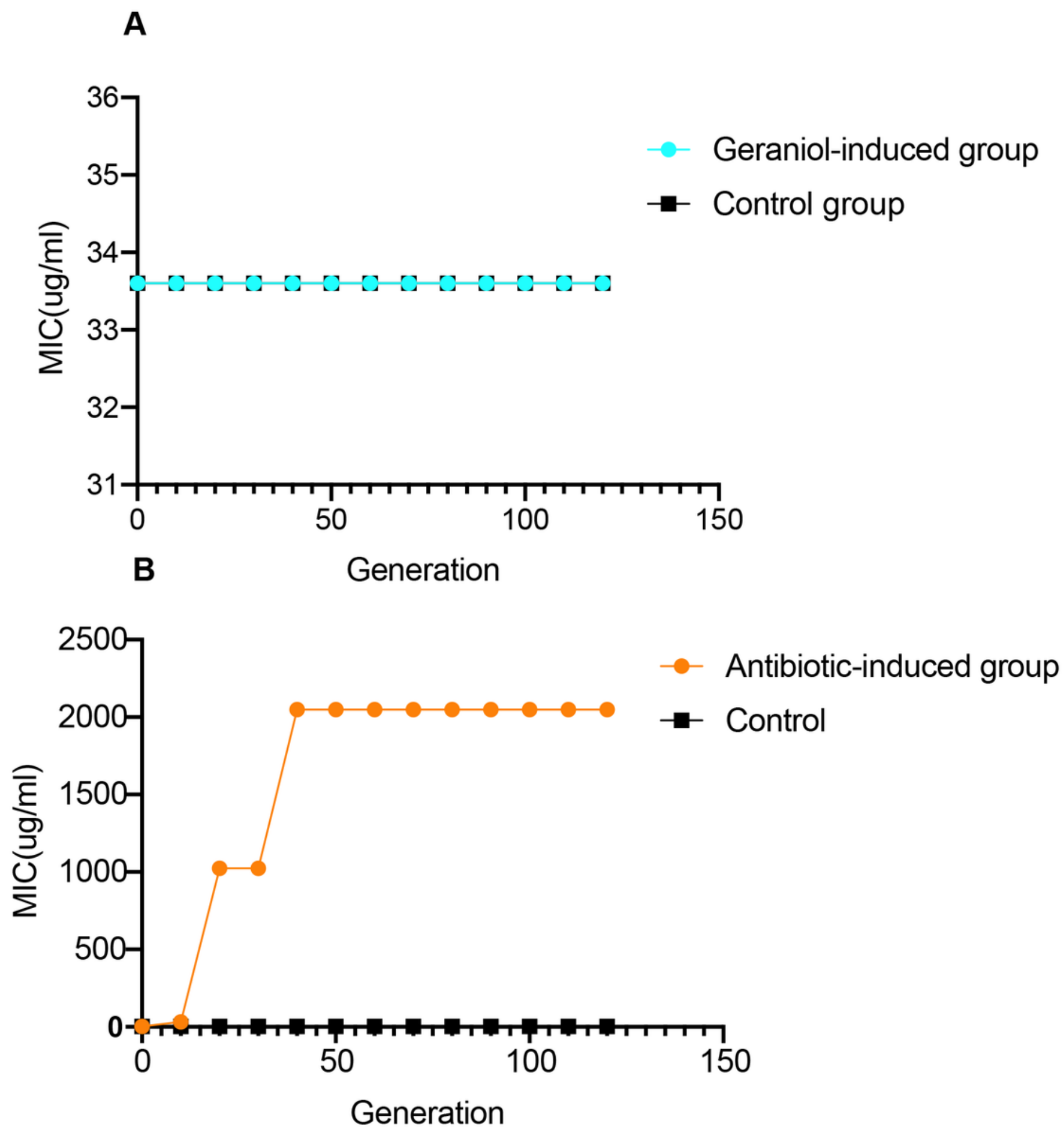

Figure 11

Effects of drug resistance of bacteria to geraniol and amoxicillin via passage cultivation with subinhibitory concentrations of drug. (A) Dynamic changes of MIC value of geraniol to the Escherichia coli strain ATCC25922 from 1-120 generations of subculture at sub-inhibitory concentration (1/2MIC). (B) Dynamic changes of MIC value of amoxicillin to the Escherichia coli strain ATCC25922 from 1-120 generations of subculture at sub-inhibitory concentration (1/2MIC). 


\section{Supplementary Files}

This is a list of supplementary files associated with this preprint. Click to download.

- Fig.S.Legend.docx

- Fig.S1.pdf

- Fig.S2.pdf

- Fig.S3.pdf

- Fig.S4.pdf

- Fig.S5.pdf

- Fig.S6.pdf

- Fig.S7.pdf

- Fig.S8.pdf

- Fig.S9.pdf

- Fig.S10.pdf

- Fig.S11.pdf

- TableS1.xIsx

- Tables2.docx

- TableS3.docx

- Tables4.docx

- Tables5.xls

- Tables6.xls

- Tables7.xls

- Tables8.xls

- Tables9.xls 